\title{
DIDŽIOSIOS BRITANIJOS KARINIS DIPLOMATINIS ATSTOVAVIMAS LIETUVOJE IKI VALSTYBINGUMO PRIPAŽINIMO DE FACTO
} (1918 m. gruodis-1919 m. rugsèjis)

\author{
Dr. Edmundas Gimžauskas \\ Lietuvos istorijos institutas
}

Bet kuriam istorijos tyrejjui, besigilinančiam ị labai ịdomų, turtingą ivvkių ir faktų, tačiau kartu ir itin painų, prieštaringą pirmųjų tarpukario nepriklausomos Lietuvos valstybės gyvavimo metų laikotarpi, neišvengiamai tenka susidurti su vienokiomis ar kitokiomis Vakarų šalių reprezentantų Lietuvoje veiklos apraiškomis. İdomiausia, jog Lietuva tada dar nebuvo užmezgusi oficialių diplomatinių santykių su tomis šalimis, vadinasi, nebuvo ir tų šalių oficialių atstovų, tačiau kai kurie Vakarų šalių reprezentantai bent jau epizodiškai figūruoja dažname to meto istoriniame siužete: ne tik užsienio ir karinèje politikoje, bet ir valstybès vidaus gyvenime. Jau vien tai liudija išskirtinị, ypatingą tų atstovų vaidmeni pradiniame moderniosios Lietuvos valstybingumo raidos etape. Dar daugiau: iš pažiūros kai kada atrodo, jog tam tikru metu šie asmenys buvo savotiškas „balsas iš viršaus“ aukščiausiems Lietuvos vadovams ar savo rankose laikè tolesnį valstybès likimą. Pvz., 1920 m. sausị D. Britanijos plk. H. Rowanas-Robinsonas teikè politinius pageidavimus dèl Lietuvos kariuomenès vidaus sutvarkymo pačiam Lietuvos prezidentui ${ }^{1}$. O 1919 m. rugsèjo pabaigoje kitas britas plk. R. B. Wardas „kèlè pirtị“ dèl galimų taikos derybų su bolševikais premjerui Mykolui Sleževičiui².

\footnotetext{
Gaigalaitė A. Lietuva Paryžiuje 1919 metais, Kaunas, 1999, p. 136.

2 Laurinavičius Č. Lietuvos-Sovietų Rusijos taikos sutartis, Vilnius, 1992, p. 44, 46. Posakis „kèlè pirtị“ - šio darbo autoriaus.
} 
Didžiosios Britanijos karinis diplomatinis atstovavimas Lietuvoje iki valstybingumo pripažinimo de facto (1918 m. gruodis-1919 m. rugsèjis)

Tačiau paradoksalu tai, kad vos po kelerių metų tokie neoficialūs Vakarų atstovai (paprastai kariškiai) kone be pėdsakų dingo iš valstybės politinio gyvenimo, nepalikę ryškesnio pėdsako, netgi savo vardų (ir taip apsunkino atliekant istorijos tyrimus jų tapatybès nustatymo darbą). Istoriografijoje savo ruožtu tokių neoficialių pirmųjų užsienio valstybių pasiuntinių veikla Lietuvoje iki pat mūsų dienų ne tik kad nebuvo išsamiau tirta, bet netgi elementariai ir aiškiai apibūdinta nepaisant, kaip jau minejjome, temos svarbos bendrų istorijos tyrimų kontekste ${ }^{3}$. Dèl to mokslo darbuose,

3 Istorikas P. Čepènas savo solidžios knygos net vieną (XV) skyrių yra paskyręs pirmụjų užsienio valstybių pasiuntinių veiklai Lietuvoje pristatyti (skyrius „Karinès ir diplomatinès misijos Lietuvoje“). Tačiau tenka konstatuoti, kad šis skyrius, palyginti su kitomis P. Čepéno veikalo dalimis, nèra toks išsamus ir apskritai atrodo gana blankus. Šiek tiek išsamiau jame pristatyta tik amerikiečiu karine misija, o prancūzų ir britų - paminètos epizodiškai. Tai lyg ir suprantama: P. Čepenas savo darbą rašè išeivijoje, JAV, todèl pirmiausia naudojosi prieinama tos šalies istoriografija šiuo klausimu, o Lietuvoje (ir Europoje) esanti archyvinè medžiaga jam buvo nepasiekiama. Žr.: Čepènas P., Naujụjų laikų Lietuvos istorija, t. 2, Vilnius, 1992, p. 477-486.

Kitas lietuvių išeivijos istorikas K. Ališauskas savo knygos II dalies IX skyriaus atskirame poskyryje taip pat itin glaustai pristato „svetimų valstybių karo misijas Lietuvoje“. Žr.: Ališauskas K. Kovos dèl Lietuvos nepriklausomybès 1918-1920, t. 1. Čikaga, 1972, p. 328-331. Jis taip pat daugiausia demesio skyré amerikiečių misijai (šioje knygoje jis atskirai aptarẻ Prancūzijos generolo H. A. Niesselio užduotị dẻl bermontininkų iškraustymo).

Istorikè A. Gaigalaitè pirmiesiems užsienio pasiuntiniams Lietuvoje apibūdinti savo knygoje irgi rado vietos - skyriuje „Antantès misijos Lietuvoje“. (Gaigalaitė A. Lietuva Paryžiuje 1919 metais, p. 117-130). Šis pristatymas jau paremtas ne tik istoriografija, bet ir tam tikra archyvine medžiaga, tačiau vẻlgi yra nenuoseklus, fragmentiškas pirmiausia dèl to, jog ị misijų veiklą autore buvo objektyviai suinteresuota žvelgti pro tarptautinès Paryžiaus taikos konferencijos prizmę ir neturejjo tikslo gilintis ị šių misijų veiklą. Tai daugmaž ir viskas, ką pirmujjų užsienio valstybių pasiuntinių veiklos tema galètume rasti lietuviškojoje istoriografijoje. Daugelis užsienio autorių savo darbuose vienaip ar kitaip paliete šią temą, tačiau, kiek žinoma, neatlikta nè vieno specialaus užsienio misijų veiklos Lietuvoje tyrimo.

Taip jau sutapo, kad rengiant ši straipsnį Kauno Vytauto Didžiojo universitete istorike E. Gruzdienè apgynė disertacija „Užsienio valstybių karinès misijos pirmojoje Lietuvos respublikoje 1919-1920 metais“. Dar prieš disertacijos gynimą teko susipažinti su šiuo išties daugeliu aspektų solidžiu ir reikšmingu darbu. Tenka pripažinti, jog jis tikrai bus naudingas bandant užpildyti daugelį lietuviškosios istoriografijos spragų. Neabejotinai stipriausia E. Gruzdienès darbo pusè - naracija, paremta archyvine, pirmiausia - užsienio, medžiaga. 
kuriuose vienokiu ar kitokiu aspektu paliesta ši tema, vis pasitaiko įvairių dalykinių netikslumų ar su ja susijusių klaidingų interpretacijų ${ }^{4}$. Ir jų vis daugèja, nes tyrẻjai vieni iš kitų perrašo klaidingus duomenis, nes neturi galimybių jų patikrinti pirminiais šaltiniais grindžiamais specialiais tyrimais ${ }^{5}$.

4 Pvz., A. Gaigalaitè rašo: „Tuo pat metu, kai į Lietuvą atvyko Prancūzijos karinė misija, kovo 22 d. Liepojoje išsilaipino nauja Anglijos karinè ir politine misija. Jai vadovavo majoras George F. Keenan. Tai jau buvo oficialus Anglijos atstovo paskyrimas i Baltijos šalis." (Gaigalaitė A. Lietuva Paryžiuje 1919 metais, p. 121). Cituotame tekste įžvelgtume netgi keletą netikslumų. Pirma, $1919 \mathrm{~m}$. kovo mènesį Liepojoje tikrai išsilaipino britu misija, tačiau jai vadovavo ne majoras George'as F. Keenanas, o majoras Austinas Henris Keenanas (žr. 29 nuorodą). O George’as Kennanas ( ne Keenanas) buvo amerikiečių telegrafo darbuotojas, žurnalistas ir publicistas. Amerikietis supainiotas su britu, turinčiu labai panašią pavardę, matyt, dèl to, kad jis (kaip, beje, ir britas) prieš I pasaulinį karą gyveno Rusijoje ir parašè keletą knygų rusiška tematika. Antra, majoro A. H. Keenano atvykimo ị Liepoją niekaip negalètume pavadinti „oficialiu Anglijos atstovo paskyrimu i Baltijos šalis“ jau vien dèl to, kad Baltijos šalys tuo metu dar buvo D. Britanijos nepripažintos ir paskyrimai galèjo būti tik neoficialūs. Be to, majoras A. H. Keenanas buvo žvalgybininkas ir vykdè daugiausia žvalgybos užduotis, o tai iš principo nesuderinama su bet kokiu oficialumu.

5 Pavyzdị, kaip tyrejai vieni nuo kitų persirašo netikslius ar klaidingus duomenis, galime rasti tame pačiame ankstesnejje nuorodoje cituotame A. Gaigalaitẻs tekste (kuriame ji rašo, kad Anglijos misijos nariai Liepojoje išsilaipino kovo $22 \mathrm{~d}$.). Minètos datos istorikè neparemia jokia nuoroda. Tačiau P. Čepenas savo knygoje taip pat teigia, kad Keenano misija ị Liepoją atvyko 1919 m. kovo 22 d. (Čepènas P. Naujųjų laikų Lietuvos istorija, p. 482), tačiau šio teiginio nepagrindžia jokia nuoroda. Vadinasi, galime pagrịstai manyti, jog A. Gaigalaitė (kuri parašè knygą vèliau) šią datą paprasčiausiai perrašè iš P. Čepèno studijos, tačiau nepabande patikrinti jos patikimumo. Aišku, galètume gana pagrịstai spèti, jog P. Čepenas šią datą rado kokiame nors JAV dokumentų rinkinyje Paryžiaus taikos konferencijos veiklai aptarti, kuris jam išeivijoje buvo nesunkiai prieinamas. Tačiau tai vis dèlto tik spèlionès, o ne faktas. Kaip ir tai, kad A. Gaigalaite, negalèdama patikrinti P. Čepèno teiginio, paprasčiausiai prièmè ji neverifikuotą, tačiau kartu nenorėjo pernelyg dažnai atvirai šiuo autoriumi remtis savo tyrime. Tačiau tai, kad ši istorike, rašydama apie Antantès misijas, daugiausia rèmèsi P. Čepènu, akivaizdu pastebejjus, jog ir kiti ankstesneje nuorodoje minèti jos teksto netikslumai perimti iš P. Čepẻno teksto. Nes būtent jis majorą Keenaną savo knygos asmenvardžių rodykleje nurodo kaip „Keenan George F.“ (p. 809). Taip pat iškart po Keenano misijos pristatymo rašo: „Ligi Anglijos diplomatinès misijos oficialaus atstovo paskyrimo ị Pabaltijo valstybes jose veikè su laivyno eskadra atvykęs neoficialus britų diplomatas H. A. Grant Watson“" (p. 482). Nors akivaizdu, kad P. Čepènas šiuo „oficialiu atstovu“ laiko visai ne majorą Keenaną, A. Gaigalaitę suklaidino nenuoseklus ir miglotas P. Čepèno pristatymas. 
Šia tema besidomintiems žinoma, kad 1919 m. Lietuvoje ịsikūrè ir èmè veikti Prancūzijos, JAV ir D. Britanijos neoficialūs atstovai. Dẻl tam tikrų veiksnių ir priežasčių pastarosios valstybès atstovų veikla buvo išskirtinè. Svarbiausia čia gal tai, kad D. Britanija pirmoji (1919 m. rugsèjî) iš Antantès šalių pripažino nepriklausomą Lietuvą bent jau de facto. Lietuvoje šis pripažinimas buvo įvertintas kaip ypač reikšmingas tolesniame valstybės raidos ir jos ịtvirtinimo etape. Kitas ne mažiau svarbus dalykas, galbūt tiesioginè paskata šiam nedidelès apimties tyrimui atlikti - tam tikras D. Britanijos to meto veiklos Lietuvoje originalumas, jos organizavimo specifika. Būtent pastarasis aspektas (bent kelių struktūrų veikimas vienu metu ir kompetencijų pasiskirstymas) mūsų istoriografijoje yra kone „perbrendęs“ dalykas, tad manytume, jog pirmiausia jau vien dèl to verta siekti bent šiokio tokio argumentais pagrịsto aiškumo ${ }^{6}$.

6 Istorikẻ E. Gruzdienė minètoje disertacijoje išsamiai analizuoja taip pat ir pirmujų neoficialių D. Britanijos pasiuntinių Lietuvoje veiklą ir misijų struktūras. Ypač išsamus yra jos atliktas karininko S. Tallentso vadovaujamos britų misijos struktūros ir veiklos tyrimas, paremtas D. Britanijos užsienio reikalų ministerijos archyviniais duomenimis. Silpnesnè dalis - daugiau karinès, o ne diplomatinès britų pasiuntinių veiklos (pirmiausia gen. H. Gougho misijos ir su ja susijusių struktūrų) tyrimas. Siekiant išsamumo tiriant būtent šiuo aspektu pagal E. Gruzdienès pasirinktą darbo modelį būtų tekę pirmiausia remtis to meto D. Britanijos karo ministerijos (War Office) duomenimis, kurie istorikei turbūt buvo neprieinami. Istorikès pasirinktas disertacijos dėstymo stilius „statiškas“, t. y. kaip naracijos pagrindas paimta iš esmès formali misijų ir pasiuntinybių struktūrinè schema, kurios elementai dažnai „persidengia“ ir susipina tarpusavyje. Toks istorinio pasakojimo organizavimo principas savaime nèra kritikuotinas ir gan tinkamas analizuojant prancūzų, iš dalies gal ir amerikiečių misijų veiklą. Tačiau aptariant britų misiją kaip tik ir išryškejja pernelyg akivaizdus jo „nenatūralumas“, „dirbtinumas“. Pirmiausia kliūva tam tikri teksto pasikartojimai, didžiulès nuorodos, nutrūkstantis ir kitoje vietoje vèl staiga „išnyrantis“ siužetas. Numatydami, jog britų pasiuntinių veiklą bus sunku „isprausti“ $\mathfrak{i}$ formalius rèmus, ir siekdami aiškumo ir paprastumo, pasirinkome ,judresnị medžiagos perteikimo modelį - chronologinio dèstymo principą, kad pasakojimo pagrindas būtų ypač ekspresyvūs to meto įvykiai, labai sparčiai besikeičianti rytinių Baltijos pakraščių regiono politinè ir karinè situacija. Britų veikimas kaip tik buvo pritaikytas tokiems spartiems pokyčiams, todèl ir atitinkamas medžiagos perteikimo modelis galètų teikti tam tikrų privalumų.

Siekiant patikslinti visas aplinkybes reikètų pasakyti, kad su E. Gruzdienès darbu teko susipažinti jau beveik baigiant savo tyrimą, todèl dèl suprantamų objektyvių priežasčių negalèjome pasinaudoti jo privalumais. Vis dèlto turint omenyje, kad vienas stipriausių minètos disertacijos elementų yra S. Tallentso misijos veiklos analizè, o jūsų dėmesiui pateiktas tyrimas baigiamas kaip tik šios misijos Kaune struktūros pristatymu - tai Lietuvos istorio- 


\section{DIDŽIOSIOS BRITANIJOS ATSTOVAVIMO LIETUVOJE FORMAVIMOSI YPATUMAI}

1918 m. lapkričio pabaigoje D. Britanijos VI lengvųjų kreiserių eskadra iš bazès Kopenhagoje buvo pasiųsta link rytinių Baltijos jūros pakrančių7. Eskadrai vadovavo kontradmirolas Edvinas Alexanderis Sinclairas. Jis vyriausybès buvo instruktuotas dèl pavestų uždavinių ir tikslų. Vienas jų buvo aprūpinti ginklais su bolševikais kovojančius estus ${ }^{8}$. Gruodžio $1 \mathrm{~d}$. Sinclairo pajègos pasiekè Liepoją. Britai čia perdavè nedaug ginklų ir latviams. Jie pareiškè, kad atvyko užtikrinti tvarkos ir kartu kovos su bolševizmu. Kitą dieną keli britų laivai ịplaukè ir ị Ventspilio uostą. Gruodžio $6 \mathrm{~d}$. Karlio Ulmanio vyriausybė formaliai paprašė britų apsaugos nuo be-

grafijoje visiškai nauji duomenys (E. Gruzdienè archyvinius duomenis šia tema panaudojo pirmą kartą) - teko pasinaudoti jos konkrečiu indèliu. Tačiau manome, jog vis dèlto pavyko išsaugoti tam tikrą savarankiškumą ir originalumą, kadangi tie patys faktai šiame straipsnyje igijo šiek tiek kitokią prasmę ir padès interpretuoti ir kitus istorijos reiškinius.

E. Gruzdienè pastebėjo istoriografijos britų pasiuntinybių klausimu netikslumų ir ị tai atkreipé dèmesị (nes jos naudotų dokumentinių šaltinių informacija ir istoriografiniai teiginiai kartais pernelyg skiriasi), tačiau nepareiškè savo, kaip tyrèjos, nuomonès ir nepašalino šių netikslumų. Ji nesuteikè prioriteto originaliai archyvinei informacijai, kurią rado, o tai, manome, iš principo neteisinga. Užuot ištaisiusi netikslumus, savotišku būdu pabandè „sutaikyti“ gana prieštaringus teiginius. Taip disertacijoje atsirado dirbtinoku loginių konstrukcijų, pvz., kalbant apie tris S. Tallentso misijos raidos etapus. Čia istorikè aiškiai be pagrindo pirmajame etape sujungia $1919 \mathrm{~m}$. kovo mèn. asmeninị S. Tallentso apsilankymą Baltijos regione ir 1919 m. gegužès-rugpjūčio mèn. laikotarpị, kai tas pats S. Tallentsas vèl atvyko ị regioną, tik jau kaip aiškiai apibrěžtus, dokumentiškai užfiksuotus tikslus turinčios pasiuntinybės vadovas (p. 52-53). Tačiau tai jokiu būdu nesumenkina E. Gruzdienès atlikto originalaus istorinio tyrimo vertès.

7 Eskadrą sudare 5 kreiseriai, 9 eskadriniai minininkai ir keletas mažesnių laivų (minų tralerių ir kt.) (Anderson E. Die baltische Frage und die internationale Politik der alliierten und assoziierten Mächte 1918-1921 // Von den baltischen Provinzen zu den baltischen Staaten 1918-1920, Bd. 2, Marburg, 1977, S. 332).

8 D. Britanijos vyriausybè, vadinamasis „karo kabinetas“, laivyną ị Baltiją pasiųsti nutare $1918 \mathrm{~m}$. lapkričio $20 \mathrm{~d}$. Tą pačią dieną $\mathrm{D}$. Britanijos užsienio reikalų ministerijos atstovas lordas Robertas Cecilas, dalyvaujant generalinių kariuomenès ir jūrų laivyno štabų atstovams, informavo Estijos vyriausybės pasiuntinius Londone Antsą Piipą, Mikhelį Martną ir Eduardą Virgo, kad britų laivynas pasiųstas ị Baltiją ir estų pajegos bus aprūpintos ginklais (Anderson E. Die baltische Frage und die internationale Politik, S. 331). 
siartinančių sovietų pajėgų . Tuo metu D. Britanijos laivynas plaukè toliau link Estijos krantų. Gruodžio 12 d. jis pasiekẻ Revelio (Talino) uostą ir čia perdavè estams 300 kulkosvaidžių, 2 patrankas, amunicijos, drabužių, organizavo karių mokymus. Gruodžio $14 \mathrm{~d}$. britai pagelbejo estams iš laivų apšaudydami bolševikų pozicijas. Po to estai iš jų gavo dar 4 patrankas, 100 kulkosvaidžių ir 5000 šautuvų $^{10}$. Prie Estijos krantų liko keli D. Britanijos laivai, o pagrindinès eskadros pajègos vèl pasuko link Latvijos.

Besikuriančios Lietuvos vyriausybė Vilniuje taip pat sužinojo apie atplaukusią britų eskadrą ir ėmèsi žygių su jais susisiekti. 1918 m. gruodžio 5 d. premjeras Augustinas Voldemaras suteikè igaliojimus Aleksandrui Stulginskiui, Petrui Leonavičiui ir G. Enakijevui (Enakieff Esquires) vykti $\mathfrak{i}$ Liepoją ir susitikti su britais ${ }^{11}$. Tačiau delegacija pavèlavo - laivynas jau buvo išplaukęs link Estijos. Liepojos burmistras informavo lietuvių pasiuntinius, jog britai pareiškę, kad „Antantès laivyno uždavinys - globoti Pabaltmario pakraščius nuo Liepojos ligi Kronštadto“" ${ }^{12}$. Tačiau kokia forma planuota šią globą suteikti, delegacijai nepavyko išsiaiškinti. Gruodžio $9 \mathrm{~d}$. delegatai jau buvo grị̌ę ì Vilnių, ir A. Voldemaro vyriausybè tuoj pat nutare pasiųsti ì Liepoją kitą delegaciją ${ }^{13}$. Gruodžio 12 d. ji jau buvo vietoje, bet sausumoje vis dar šeimininkaujantys vokiečiai sutrukde susitikti su D. Britanijos laivyno vadu ${ }^{14}$. E. Sinclairas kaip tik gruodžio $15 \mathrm{~d}$. buvo nutaręs ginti jau ir Latviją ${ }^{15}$. Gruodžio 19 d. lietuviams vèl nepavyko su juo pasimatyti dèl vokiečių daromų kliūčių ${ }^{16}$. Pagaliau gruodžio $23 \mathrm{~d}$. delegaciją priemè vieno britų laivo kapitonas, bet kai iš jo buvo paprašyta Lietuvai ginklų ir amunicijos, atsakè, jog be Londono ži-

\footnotetext{
9 Ten pat, p. 334.

10 Ten pat.

11 A. Voldemaro $1918 \mathrm{~m}$. gruodžio 5 d. išduotas sertifikatas. Lietuvos centrinis valstybès archyvas (toliau - LCVA), f 923, ap. 1, b 3, 1. 314.

121918 m. gruodžio 9 d. delegacijos ị Liepoją ataskaita. LCVA, f 923, ap. 1, b. 3, 1. 310.

1319181209 Lietuvos vyriausybès posedžio protokolas. LCVA, f. 923, ap. 1, b. 9, 1. 26.

14 P. Leonavičiaus pranešimas 19181225 Lietuvos vyriausybès posėdyje. LCVA, f. 923, ap. 1, b. $9,1.36$.
}

15 Anderson E. Die baltische Frage und die internationale Politik, S. 334.

16 P. Leonavičiaus pranešimas 19181225 Lietuvos vyriausybès posėdyje. LCVA, f. 923, ap. 1, b. $9,1.36$. 
nios nieko duoti negalįs, ir patarè šiais klausimais kreiptis ị vyriausybę ${ }^{17}$. Gruodžio 25 d. ̣̇ Vilnių grịžusiai delegacijai susidarè ịspūdis, jog „apie mūsų kraštą anglai nieko nežino" ${ }^{18}$. Vis dèlto šis vizitas turejjo ir šiokių tokių praktinių padarinių: jos narys Kazimieras Vizbaras, likęs Latvijoje ir po to jau negalèjęs parvykti ị bolševikų užimtą Vilnių, tų pačių britų patartas, 1919 m. sausio 3 d. jų eskadriniu minininku „Princess Margaret“ išvyko ị Angliją. Čia kartu su Jonu Šliūpu, vietos lietuvių padedamas, ìsteigè neoficialią Lietuvos atstovybę ${ }^{19}$.

Naujoji M. Sleževičiaus kairiųjų vyriausybė, sudaryta 1918 m. gruodžio pabaigoje, taip pat aktyviai stengèsi susisiekti su britais. Dar $1918 \mathrm{~m}$. gruodžio $31 \mathrm{~d}$. jos posėdyje buvo nutarta pasiųsti inžinierių Vincą Čepinskị „igaliotiniu $\mathfrak{i}$ Rygą tartis su Latvių ir Anglų civiline ir karine valdžia" ${ }^{20}$. Sausio $10 \mathrm{~d}$. kabineto posėdyje V. Čepinskis jau skaitė pranešimą apie savo kelionę i Latviją. Tiesiogiai susitikti su britais, matyt, jam taip pat nepavyko, nes informavo, kad „latvių nupasakojimu, adm. Sinkleris sakè, kad anglai padèsią lietuviams tik tada, jeigu patys lietuviai norès susiorganizuoti ir apginti Vilnių “21.

1919 m. sausio pradžioje susiklosčiusi situacija visiems Pabaltijo judejjimams dèl nepriklausomybès buvo itin nepalanki. Sausio $3 \mathrm{~d}$. britu laivynas, o kartu ir latvių bei vokiečių kariniai daliniai besiartinant sovietinèms pajègoms apleido Rygą; tą pačią dieną britai iš Estijos atsitraukè $\mathfrak{i}$ Helsinkij ${ }^{22}$. Atsitraukiančios latvių ir vokiečių pajègos greitai bolševikų buvo prispaustos Kuršo kampe, prie jūros - Liepojoje ir šalia jos. Lietuvoje užèmę Vilnių bolševikai sparčiai veržèsi ị vakarinę jos dalị. Tuo metu Baltijos jūroje buvo performuotas D. Britanijos laivynas. Jam vadovauti buvo paskirtas energingas admirolas Walteris Cowanas, iki tol vadovavęs 1-ajai lengvụjų kreiserių eskadrai ${ }^{23}$. Sausio $17 \mathrm{~d}$. jis su šiomis

17 Ten pat.

18 Ten pat.

19 Iš mūsų atstovybès angluose // Lietuva, 1919, Nr. 146, p. 1.

2019181231 Lietuvos vyriausybès posedžio protokolas. LCVA, f. 923, ap. 1, b. 9, 1. 55 a.p.

${ }^{21} 19190110$ Lietuvos vyriausybès posèdžio protokolas. LCVA, f. 923, ap. 1, b. 24, 1. 243 a. p.

${ }_{22}$ Anderson E. Die baltische Frage und die internationale Politik, S. 337.

${ }^{23}$ Kontradmirolui E. Sinclairui ir net patiems britų admiraliteto atstovams Londone nuo pat $1918 \mathrm{~m}$. lapkričio trūko aiškių vyriausybès instrukcijų dèl veikimo Baltijos jūroje. Labiausiai juos jaudino klausimas, ar D. Britanija kariaus su sovietine Rusija, ką turejo liudyti 
pajėgomis pirmą kartą apsilankè Liepojoje, kurios padètis buvo daugiau nei rimta ${ }^{24}$. Reikalus labai komplikavo neaiškūs britų ir vokiečių tarpusavio santykiai. Tačiau vasario $6 \mathrm{~d}$. jau pati Vokietija oficialiai paprašè britų laivyno paramos Baltijos uostuose, ir tai tapo bendradarbiavimo kovojant su bolševikais pagrindu. Vokietija vadovauti savo igulai Liepojoje atsiuntė energingą generolą Rudigerị von der Goltzą (beje, netrukus tapusį ne mažesniu nei bolševikai, o gal net ir klastingesniu judejjimų dèl nepriklausomybès priešu $)^{25}$. Vasario pradžioje bendromis pastangomis bolševikai buvo atstumti tolyn nuo Liepojos ir iš jų atsiimtas Ventspilio uostas. Vasario $21 \mathrm{~d}$. karinis D. Britanijos laivynas vèl išplaukè tolyn nuo Latvijos pakrančių ${ }^{26}$, kur vis labiau ịsitvirtino vokiečiai, permetę čia netgi savo naujus būrius iš Vokietijos.

Kartu britai stengèsi nuodugniau ištirti padèti vietose, išsiaiškinti veiksmų perspektyvas rytineje Baltijos pakranteje. Taip pat buvo siekiama palaikyti kiek ịmanoma pastovesnị ryši su vietinių politinių judejjimų atstovais. Kontradmirolui E. Sinclairui eskadros ekspedicijos metu politiniais klausimais patarinejo profesionalus diplomatas Vivianas Bosanqu-

atitinkami veiksmai. Tačiau Antantès šalys neturèjo vienos aiškios pozicijos dèl bolševikų, o Vakarų šalių kariuomenès ir laivynai - ilgalaikio veiksmų plano. 1918-1919 m. sandūroje britų ir amerikiečių politikai netgi buvo nutarę išvis nutraukti intervenciją i Rusiją - dèl to iš Rygos ir Talino buvo atšauktas D. Britanijos laivynas. E. Sinclairas, kuris ir šiaip nebuvo iniciatyvus, sausio $6 \mathrm{~d}$. atvyko laivu i Kopenhagą ir perdavė pareigas admirolui W. Cowanui, kurio 1-ąją lengvụjų kreiserių eskadrą tuomet sudare tik du kreiseriai ir penki eskadriniai minininkai. Pradejęs vadovauti visam D. Britanijos kariniam laivynui Baltijos jūroje, jis gavo pavedimą perimti E. Sinclairo Liepojoje ir Helsinkyje paliktus kelis laivus. W. Cowanas garsejo iniciatyvumu, kovingu entuziazmu, todèl jam vadovaujant dar E. Sinclairui vadovybès duota komanda „parodyti britų vèliavą“ Baltijoje, èmè ịgauti realų turinị. Pagrindiniai W. Cowano eskadros veiksmai buvo nukreipti ị Kronštadto uosto blokavimą, kad iš ten $\mathfrak{i}$ atvirą jūrą negalètų išplaukti sovietiniai laivai (Anderson E. Die baltische Frage und die internationale Politik. S. 332, 337, 344).

24 Ten pat, p. 345.

25 Rudigerio von der Goltzo požiūris ị Baltijos šalių valstybingumą atsispindi jo atsiminimų knygoje, skirtoje aptariamam laikotarpiui (R. von der Goltz. Meine Sendung in Finland und im Baltikum, Leipzig, 1920).

26 Anderson E. Die baltische Frage und die internationale Politik, S. 346. Vasario 9 d. admirolas W. Cowanas latviams perdave 5000 šautuvų, 50 kulkosvaidžių ir $5 \mathrm{mln}$. šovinių. Tačiau R. von der Goltzo vadovaujamos vokiečių pajègos šio karinio turto neleido iškrauti iš jị atgabenusio Latvijos laivo „Saratov“ ir išdalyti latvių kariams. Motyvuota tuo, jog esą latvių visuomenè pati yra „pusiau bolševikine““ (ten pat, p. 345-346). 
etas, D. Britanijos konsulas Rygoje prieš I pasaulinị karą ${ }^{27}$. Jis 1919 m. ir toliau ejjo konsultanto pareigas, be to, netrukus jam talkininkauti D. Britanijos užsienio reikalų ministerija paskyrè kitą profesionalų savo atstovybès Kopenhagoje diplomatą - Herbertą Grantą Watsoną. Jis jau 1919 m. vasarị su britų laivynu apsilankè rytinèje Baltijos pakrantėje ${ }^{28} .1919 \mathrm{~m}$. vasario viduryje D. Britanijos vyriausybè nutarè i Liepoją nusiųsti pirmąją nuolatinę misiją, vadovaujamą žvalgybos karininko A. Keenano (Keenan Austin Henry), prieš karą dirbusio linų pirkliu Piarnu (Estijoje) ${ }^{29}$. Jis su keliais bendradarbiais turejo ịvertinti naujųjų Baltijos šalių vyriausybių stabilumą ir jų kreditavimo iš britų pusès, taip pat D. Britanijos ekonominių interesų užtikrinimo (linų, miško medžiagos tiekimo) tęstinumo galimybes $^{30}$. Svarbią ịpareigojimų dalị sudarè vokiečių kariškių ir vietos

${ }^{27}$ Lenz W. Zur britischen Politik gegenüber den baltischen Deutschen 1918/19 // Das Vergangene und die Geschichte, Göttingen, 1973, S. 274, 283; Штейнберг В. Джентельмены в Латвии (1917-1920), Рига, 1983, с. 87.

${ }^{28}$ Anderson E. Die baltische Frage und die internationale Politik, S. 347.

${ }^{29}$ Lenz W. Zur britischen Politik gegenüber den baltischen Deutschen 1918/19, S. 276. Istorikas P. Čepenas, remdamasis S. Tallentso atsiminimais, rašo, jog A. H. Keenanas prieš I pasaulinį karą atstovavo privačiai Anglijos prekybos bendrovei Rygoje (Čepėnas $\mathbf{P}$. Naujụjų laikų Lietuvos istorija, p. 482). Iš ịvairiuose istoriniuose šaltiniuose surankiotų detalių pavyko sudaryti maždaug toki šio britų pasiuntinio, 1919-1920 m. suvaidinusio reikšmingą vaidmenị įtvirtinant Lietuvos valstybingumą, biografinị portretą: Keenanas Austinas Henry (1887-1957), kilęs iš Škotijos, Dandi (Dundee) miesto. Jauniausias Tomo Keenano, tekstilès (džiuto) verslininko, sūnus. Išsilavinimą igijo Niuporte (Newport), verslo karjerą pradejjo linų pirklių firmoje „Messrs Corrie Machie and Co“. Nuo $1914 \mathrm{~m}$. tarnavo „The Black Watch“ karinejje teritorinès gynybos dalyje tame pačiame Dandi mieste. $1915 \mathrm{~m}$. kovą gavo jaunesniojo leitenanto, 1916 liepą - leitenanto laipsni. Tarnavo 4-ajame „The Black Watch“ batalione, karo pabaigoje jam buvo suteiktas majoro laipsnis. 1919 m. pradžioje vykdyti specialaus pavedimo buvo atsiųstas ị besikuriančias Baltijos šalis, veikè daugiausia Latvijoje. $1920 \mathrm{~m}$. britų deleguotas ị Tautų Sąjungos kontrolès komisiją lietuvių ir lenkų ginčo ir Vilniaus problemos spręsti. Atlikęs šią misiją, toliau savo veiklą siejo su Baltijos valstybėmis: nuvyko ị Rygą, Taliną ir ten tęsé linų žaliavos verslą. Dèl II pasaulinio karo ịvykių turèjo palikti Estiją, kurioje buvo apsistojęs, ir čia igytą turtą. Vèl persikèlè ị Dandi, kur tapo džiuto ir linų prekybos firmos direktoriumi. II pasaulinio karo metais valdžios pavedimu vykdè žvalgybinę misiją Egipte. Po to dar buvo išrinktas Škotijos linų gamybininkų ir prekybininkų asociacijos viceprezidentu, Dandi miesto komercijos rūmų nariu.

${ }^{30}$ Lenz W. Zur britischen Politik gegenüber den baltischen Deutschen 1918/19, S. 276. Pagrindinis majoro A. H. Keenano komandos narys majoras Ellisas (Ellis) taip pat buvo gerai susipažinęs su Baltijos šalimis, nes anksčiau su jomis palaikè prekybinius ryšius 
vokiškosios visuomenès dalies nuotaikų ir siekių tyrimas. Taip pat buvo duotas ir ipareigojimas veikti aktyviai, bandant sutaikyti vokiečius su pabaltijiečiais, juos visus sutelkti prieš bolševikų ittaką ${ }^{31}$.

Tuo metu M. Sleževičiaus vyriausybė, jau persikèlusi ị Kauną, $1919 \mathrm{~m}$. sausio $10 \mathrm{~d}$. svarstė tolesnes valstybès perspektyvas. Neaiški geopolitinè situacija ją skatino dar kartą iš naujo ịvertinti kuriamos valstybès galimybes ir tarptautinès politinès gravitacijos vektorius. Diskusijų pagrindu, kaip matyti, tapo prekybos ir pramonès ministro Jono Šimkaus idejja suartèti su D. Britanija per Liepojos uostą ${ }^{32}$. Atrodo, lietuvių politikus stipriai paveikè tai, kad britai buvo numatę savo ịtakos zona paversti tik pakrantės ruožą nuo Liepojos iki Kronštadto: vadinasi, Lietuva nepateko ị britų ịtakos lauką, ir tai esamomis sąlygomis vienareikšmiškai buvo suprasta kaip gyvybiškai valstybingumo perspektyvoms pavojinga situacija. Dèl to kai kurie vyriausybès nariai buvo linkę siekti Liepojos bet kokia kaina. Sumanyta net nepaisyti Latvijos interesų, nes latviai ir taip „t mus skersuoja “"33. Vyriausybės diskusijose ryškejjo pageidautinas valstybès modelis: Lietuva per Liepoją gauna išejimą ị Baltiją ir taip tampa jūrine (vadinasi, Anglijai patrauklia) valstybe (Liepoja nebūtinai tiesiogiai prijungiama, galbūt išnuomojama arba valdoma bendrai - per Baltijos tautų sąjungą); rytuose (baltarusių žemėse) pasitenkinama kuklesniais (negu A. Voldemaro vyriausybès), artimesniais etnografiniams, teritoriniais reikalavimais, pirmiausia grindžiamais ekonominiais (ypač miško eksploatavimo ir eksporto) argumentais, kurie, manyta, britams yra labai svarbūs. Kaip ryškiausias diskusijų akcentas buvo iškelta Lietuvos kaip D. Britanijos protektorato ideja, kurią aktyviai gynè pats premjeras. Jis jau kitame, sausio 23 d., vyriausybès posėdyje sakè: „Ir vokiečiai, ir rusai turès agresyvius planus dèl Lietuvos - vieni mes valstybès neišlaikysime. Mums reikètų ieškoti paramos tokioje valstybejje, kuri neturètų jokio intereso kištis ị mūsų vidaus reikalus. Tokia valstybe galètų būti Anglija“"34.

\footnotetext{
(Anderson E. Die baltische Frage und die internationale Politik, S. 347).

31 Veiklos instrukcijas majoras Keenanas gavo 1919 m. vasario 24 d. (Lenz W. Zur britischen Politik gegenüber den baltischen Deutschen 1918/19, S. 284)

3219190110 Lietuvos vyriausybès posėdžio protokolas. LCVA, f. 923, ap. 1, b. 24, 1. 243.

3319190123 Lietuvos vyriausybès posėdžio protokolas. LCVA, f. 923, ap. 1, b. 24, 1. 225 a. p.

34 Ten pat.
} 
J. Šimkus teigè, kad ši valstybès priklausomybès forma garantuotų „geriausias vidaus plètojimosi sąlygas ir minimumą kišimosi ị mūsų vidaus

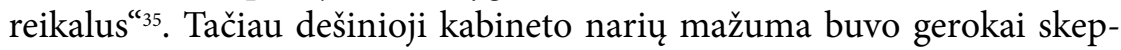
tiškesnè protektorato idejos klausimu. Jau svarstymų pradžioje, pvz., ministras be portfelio A. Stulginskis pažymèjo, kad „Lietuvai daugiau tiktų protektoratas Amerikos ${ }^{{ }^{3} 6}$. Finansų ministerijos valdytojas Voldemaras Čarneckis tiesiai pareiškè, jog tai gali nuspręsti ne vyriausybė, o tik Steigiamasis Seimas. Jis nurodè, kad šis sumanymas visuomeneje gali sukelti daug daugiau nepasitenkinimo nei ankstesnis konvencijų su Vokietija sudarymo svarstymas ${ }^{37}$. Netgi M. Sleževičiaus partijos narys vidaus reikalu ministras Jonas Vileišis pareiškè, kad tokị svarbų klausimą gali išspręsti tik Steigiamasis Seimas ${ }^{38}$. Oponentams labai vykusiai nurodžius geopolitiniame kontekste bręstančios Tautų Sąjungos, taip pat lokalios Baltijos tautų sąjungos idejjas, protektorato iniciatyva kažkaip savaime prigeso, o D. Britanijos nutarta nedelsiant prašyti tik ginklų ${ }^{39}$.

1919 m. vasario pabaigoje-kovo pradžioje Lietuva suteikè Latvijos vyriausybei gyvybiškai svarbią paskolą ir už tai išsiderèjo teisę labai palankiomis sąlygomis naudotis Liepojos uostu. K. Ulmanio vyriausybé issipareigojo „priimti siunčiamas Lietuvos vyriausybei $\mathfrak{i}$ Liepojos uostą prekes ir karo medžiagą neribotame kiekyje ${ }^{\text {" }}{ }^{40}$. Lietuvai net buvo leista pasiųsti savo kariuomenę tų prekių saugoti. Be to, už tranzitu per Latviją gabenamas prekes nereikejjo mokèti jokių muitų ${ }^{41}$. Kovo $6 \mathrm{~d}$. ị dalykinius pasitarimus su latviais ị Liepoją išvyko to paties J. Šimkaus vadovaujama Lietuvos atstovų delegacija ${ }^{42}$. Ji čia rado „diena anksčiau“ atvykusią minètą $\mathrm{A}$. Keenano vadovaujamą britų misiją ${ }^{43}$. Su ja kovo $8 \mathrm{~d}$. buvo kalba-

\footnotetext{
3519190110 Lietuvos vyriausybès posėdžio protokolas. LCVA, f. 923, ap. 1, b. 24, 1. 244.

36 Ten pat, p. 243.

37 Ten pat.

3819190123 Lietuvos vyriausybès posėdžio protokolas. LCVA, f. 923, ap. 1, b. 24, 1. 226 a. p.

39 Ten pat, 1. 227 a.p.

40 Butkus Z. Lietuvos ir Latvijos santykiai 1919-1929 metais, Vilnius, 1993, p. 20.

41 Ten pat.

42 Ten pat; 19190309 J. Šimkaus pranešimas Lietuvos vyriausybei. LCVA, f. 383, ap. 7, b. $38,1.6$.

4319190309 J. Šimkaus pranešimas Lietuvos vyriausybei. LCVA, f. 383, ap. 7, b. 38, 1. 6.
} 
masi įvairiomis temomis, įteikti D. Britanijos valdžiai skirti dokumentai. J. Šimkaus delegacija siekė per britų misiją igyti galimybę susisiekti su Londonu, užmegzti prekybos ryšius su D. Britanija. Majoras Keenanas buvo pakviestas atvykti ị Kauną, ir entuziastingai sutiko. Keenanas taip pat žadèjo apie ši susitikimą laive ịrengtomis radijo ryšio priemonèmis informuoti savo valdžią ir ị D. Britaniją nugabenti lietuvių delegacijos perduotus dokumentus ${ }^{44}$. Kovo $10 \mathrm{~d}$. dar buvo numatytas kitas lietuvių ir britų atstovų susitikimas. Jo metu Lietuvos interesus gynybos srityje reprezentuoti buvo pavesta karininkui Mykolui Gedgaudui ${ }^{45}$. Po to J. Šimkus turejo grižžti ị Kauną, o kiti delegacijos nariai su M. Gedgaudu - vykti i Estiją. Tačiau lietuviai Liepojoje užtruko ilgiau nei planavo, mat kovo 12 d. D. Britanijos laivu čia trumpam atvyko karininkas S. Tallentsas (Tallents Stephen), kuriam tiriant padèti Baltijos valstybėse buvo patikèta ypatinga misija ${ }^{46}$. Nors S. Tallentsas buvo karininkas, bet jam buvo nurodyta atkreipti dèmesị būtent ị ekonominę kraštų būklę ir gyventojų aprūpinimo situaciją. Todèl J. Šimkaus delegacija su juo susitiko pasitarti ${ }^{47}$.

Lietuvos delegacijai jau išvykus iš Liepojos (tuo metu M. Sleževičiaus vyriausybę Kaune pakeite Prano Dovydaičio kabinetas), kovo 19 d. čia nuolat dirbti atvyko minètas H. Grantas Watsonas ${ }^{48}$. Kovo 23 d. K. Ulmanis telegrafavo lietuviams, kad „atvyko Anglijos reprezentantas Latvijos ir Lietuvos vyriausybèms“49. Taip pat ir majoras Keenanas vèl laukè čia atvykstant J. Šimkaus ${ }^{50}$. Lietuvos atstovai nuvyko ị Liepoją, o balandžio 6 d. J. Šimkus ir J. Vileišis iš ten ị Kauną pirmojo vizito atlydejo H. Grantą

${ }^{44}$ Ten pat.
${ }^{45}$ Ten pat.

${ }^{46}$ Anderson E. Die baltische Frage und die internationale Politik, S. 347. Kovo pab. i D. Britaniją grižžes S. Tallentsas lordui R. Cecilui pasiūlè remti Baltijos valstybių nepriklausomybę. Šiai minčiai pritare A. Balfouras, E. Howardas, daug ịtakingų kariuomenès ir laivyno karininkų, tačiau su tuo nesutiko premjeras D. Lloydas Georgas (ten pat).

${ }^{47}$ Šiuos pasitarimus, remdamasis S. Tallentso atsiminimais, savo knygoje mini P. Čepènas (Čepènas P. Naujujų laikų Lietuvos istorija, p. 483). Tiesa, jis nenurodo pasitarimų datos, o J. Šimkus su S. Tallentsu derejosi ne kartą ir vèliau. Tačiau sprendžiant iš pasitarimų konteksto ir jų dalyvių pavardžių (inžinierius Šulcas, M. Gedgaudas) galima pagrịstai manyti, jog kalba sukasi būtent apie $1919 \mathrm{~m}$. kovo vidurio pasitarimus.

48 Anderson E. Die baltische Frage und die internationale Politik, S. 347.

4919190323 K. Ulmanio telegrama ị Kauną. LCVA, f. 383, ap. 7, b. 38, 1. 142.

5019190324 K. Ulmanio telegrama ị Kauną. LCVA, f. 383, ap. 7, b. 38, 1. 141. 
Watsoną $a^{51}$. Pastarasis Lietuvoje užsibuvo iki balandžio $17 \mathrm{~d}$. Gavęs pranešimą, kad Liepojoje vokiečiai nuverte K. Ulmanio vyriausybę, skubiai išvyko atgal ${ }^{52}$. Dar jam esant Kaune, balandžio 12 d., ị valdžią grižzo M. Sleževičius su savo bendražygiais; ankstesnes pareigas einantis J. Šimkus kartu su H. Grantu Watsonu vèl išvyko į Liepoją $a^{53}$, šikart geriau susipažinti su pasikeitusia situacija Latvijoje. M. Sleževičiaus vyriausybẻ Kaune faktiškai be trukdžių galëjo ịtvirtinti savo poziciją dèl D. Britanijos.

Tuo metu Latvijoje šeimininkavo vokiečiu pajegos su R. von der Goltzu priešakyje. Nors balandžio $3 \mathrm{~d}$. čia grịžo adm. W. Cowano eskadros laivai ${ }^{54}$ ir pasirodè Prancūzijos laivų junginys ${ }^{55}$, vokiečiai, sustiprinę ir aptvarkę savo sausumos pajeggas, jų jau ne itin paisè. K. Ulmanis su savo šalininkais buvo priverstas slëptis Liepojos uoste stovinčiame laive "Saratov“, ir tik Antantès laivyno pabūklai saugojo nuo vokiečių, kurie norèjo su jais susidoroti ${ }^{56}$. Apskritai situacija buvo labai neaiški, nes visos tarpusavyje konfliktuojančios jẻgos kartu palaikè ir formalią prieš bolševikus sudarytą sajungą. R. von der Goltzo pretenzijos dominuoti dar labiau padidèjo, kai antibolševikinès pajègos gegužès $22 \mathrm{~d}$. užèmé Rygą.

51 Svetimų valstybių atstovai Lietuvoje // Lietuva, 1919, Nr. 73, p. 2. Balandžio 7 d. H. Grantas Watsonas Kaune buvo susitikęs su vyriausybès vadovu ir A. Smetona (Lietuva, 1919, Nr. 75, p. 2). Vadinasi, P. Čepėnas savo knygoje nepagrịstai nurodo, jog H. Grantas Watsonas ị Kauną atvyko tik 1919 m. balandžio 16 d. (Čepėnas P. Naujųjų laikų Lietuvos istorija, p. 483).

52 Išvažiavo Liepojun // Lietuva, 1919, Nr. 83, p. 2; Штейнберг В. Джентельмены в Латвии (1917-1920), Рига, 1983, с. 101.

53 Išvažiavo Liepojun // Lietuva, 1919, Nr. 83, p. 2.

541919 m. balandžio 3 d. prie rytinių Baltijos pakrančių sugrịžusias admirolo W. Cowano pajègas sudarè 4 kreiseriai, 5 eskadriniai minininkai ir 5 mažesni laivai. Jie latviams gabeno 20000 šautuvų, 6 haubicas, 12 patrankų ir 20 sunkvežimių (Anderson E. Die baltische Frage und die internationale Politik, S. 346).

551919 m. kovo 27 d. Prancūzija taip pat pasiuntè ị Baltijos jūrą laivyno diviziją, vadovaujamą komandoro Brissono, kurią sudarè eskadrinis minininkas, 4 torpediniai laivai, 4 žvalgybos laivai ir ginkluota jachta. Divizijai buvo įsakyta veikti kartu su britais. Balandžio 19 d. Prancūzijos laivai pasiekė Liepoją (ten pat, p. 346-347). Po šios datos lietuvių pasiuntiniai Liepojoje savo informacijose ne kartą yra mineję susitikimus ir pokalbius su Prancūzijos laivyno atstovais, pirmiausia - pačiu komandoru Brissonu.

56 Vokiečių nuo $1919 \mathrm{~m}$. balandžio $16 \mathrm{~d}$. veiksmų prieš K. Ulmanio vyriausybę neatgrasė netgi tai, jog Liepojos uoste tuo metu stovejo D. Britanijos kreiseris ir 6 eskadriniai minininkai (ten pat, p. 346). 
Didžiosios Britanijos karinis diplomatinis atstovavimas Lietuvoje iki valstybingumo pripažinimo de facto (1918 m. gruodis-1919 m. rugsèjis)

Britų dèmesys buvo sutelktas ị ịvykius Latvijoje, todèl kontaktai su lietuviais nebebuvo tokie intensyvūs.

Visą apžvelgtaji laikotarpi (nuo 1918 m. gruodžio iki 1919 m. gegužès mėn.) galètume laikyti britų neoficialiosios, daugiau asmeninio, nei institucinio pobūdžio, atstovybės Lietuvoje kūrimo labai specifišku etapu. Tai itin išryškèja palyginus britų ir prancūzų atstovybių formavimosi ypatumus. Prancūzija savo tam tikros sudèties ir paskirties aiškiai karinę misiją j̇ Kauną atsiuntė 1919 m. kovo 19 d. ir ji čia ịsikūré ${ }^{57}$. O britai elgèsi visiškai kitaip.

Iki I pasaulinio karo pabaigos Baltijos erdvė faktiškai buvo žemyninių valstybių - Rusijos ir Vokietijos - santykių aiškinimosi laukas tiek taikos, tiek karo metu. Pagal jūrinės geopolitinès koncepcijos pradininko Halfordo Mackinderio (postulavusio jūrinių ir žemyninių valstybių permanentinès kovos idejją) schemą Baltijos erdvė aiškiai priskirtina tarpinei zonai ${ }^{58}$. Vis dèlto regionas praktiškai tiesioginiam didžiųjų jūrinių valstybių, kurios pirmiausia tapatintinos su anglosaksiškuoju pasauliu, poveikiui buvo neprieinamas. Tačiau tiek Vokietijos, tiek Rusijos sugniužimas po I pasaulinio karo (nors ir skirtingais būdais - vienos dèl pralaimèjimo, kitos - dèl bolševikų ìvykdyto perversmo) radikaliai pakeitè padètị. Rytinès Baltijos pakrantès šalių tautiniai judejjimai pajuto jūrinès didvalstybès politinị veikimą. Tai buvo visiškai nauja patirtis, kuri iš tikrųjų juos atgaivino. Šiuo atveju karinè galia buvo matuojama ne užimtų teritorijų kvadratiniais kilometrais ar péstininkų divizijų karių skaičiumi, o komunikacinių magistralių ir jas prižiūrinčių pagrindinių sausumos punktų kontrolès mastais ${ }^{59}$, taip pat karinių pajègų mobilumo galimy-

57 Išsamiausiai apie prancūzų karinę misiją Lietuvoje žr.: Gruzdienė E. Prancūzijos karinių misijų veikla Lietuvoje 1919-1920 metais // Darbai ir dienos, Kaunas, 2010, t. 54, p. 55-73.

58 Laurinavičius Č., Motieka E., Statkus N. Baltijos valstybių geopolitikos bruožai. XX amžius. Vilnius, 2005, p. 32-36.

59 D. Britanijos, kaip didžiosios jūrinès valstybès, galia buvo puikiai suvokiama ir pačių nagrinẻjamų ịvykių amžininkų. Bene akivaizdžiausiai tai atsiskleidžia per spaudą. Pvz., mažlietuvių „Tilžès keleivis“, 1919 m. birželị informuodamas skaitytojus apie tai, kad Sąjungininkai nuo Vokietijos atskyrẻ Klaipedos kraštą ligi Nemuno, suabejojo, ar „kartais nepanorètų to krašto pasilikti sau anglai, nes jie norị iš Klaipedos pasidaryti sau antrąji Gibraltarą, o iš Ezelio salos ties Ryga - naująją Maltą" (akivaizdu, jog mažlietuvių laikraštis šiuo atveju atspindejo vokišką padèties vertinimą; jame išdèstytas mintis perpasakojo 
bėmis. Pasirodė, kad visa tai efektyvu: Peterio Stučkos vadovaujami raudonieji Latvių šauliai, bene grèsmingiausia bolševikų jèga, taip ir nesugebejo paimti Liepojos, kurią (kartu su joje buvusiomis gausiomis, bet iš pradžių pakrikusiomis vokiečių pajègomis) iš jūros denge britų laivyno pabūklai ${ }^{60}$. Vèliau šie pabūklai saugojo ir gelbejjo K. Ulmanio vyriausybę ir jai ištikimus latvių dalinius nuo vokiečių. Visa tai neabejotinai imponavo Lietuvos politikams ir skatino telkti pastangas siekiant, kad Lietuva taip pat taptų jūrine valstybe. Tačiau britų politiniai ir juo labiau geopolitiniai sprendimai visada buvo labai atsargūs ir pasverti, todèl jie neskubejjo „ịrašyti“ Lietuvos ị jūrinių valstybių eilę ir steigti nuolatinès savo misijos Kaune. Pagaliau tai, kad jie tokias atstovybes ịkūre Latvijos ir Estijos pakrantėse, tuo metu visiškai nereiške, jog rengiamasi pripažinti šias nepriklausomas valstybes. Kaip, beje, ir prancūzų misijos atsiuntimas i Kauną iš esmès reiškè ne Prancūzijos pasirengimą pripažinti Lietuvą, o tai, kad ji vadovaujasi žemyninès valstybès kategorijomis.

\section{ATSTOVAVIMO PLE்TRA IR LIETUVA: BRITŲ INSTITUCIJŲ RYTINIAME BALTIJOS REGIONE KŪRIMAS}

1919 m. pavasarị Antantės šalys jautė vis didesnị nusivylimą „baltųjụ“ rusų neorganizuotumu ir nesugebejimu efektyviai kovoti su bolševikų pajègomis. Balandžio $15 \mathrm{~d}$. D. Britanijos kariuomenès generalinis štabas kreipèsi ị savo valdžią. Jis nurodẻ Sąjungininkų padarytas klaidas Suomijos ir Baltijos šalių atžvilgiu, kurios, jo manymu, sutrukde įvykdyti

Kauno oficiozas „Lietuva“ (vedamasis str. // Lietuva, 1919, Nr. 137, p. 1). O štai danų laikraščio „Berlinsgske Tidende“ korespondentas Estijoje taip matė tenykštę situaciją: „Anglai energingai žiūri savo ekonominių reikalų estų krašte. Jie reikalauja tarp kitko koncesijų geležinkeliui per Estų kraštą i Rusus. Tuo tarpu deramasi išnuomoti Anglams Dagès ir Ozilijos salas. Anglai nori ten įsteigti didelị prekybos, o gal ir karo uostą" (Iš Estų krašto // Lietuva, 1919, Nr. 185, p. 4).

${ }^{60} 1918$ m. gruodžio 16 d. E. Sinclairas pareiškė Liepojos merui A. Berziniui (Berzinš), kad jis, kaip D. Britanijos pajègų vadas, prisiima atsakomybę už viešąji saugumą teritorijoje, kurioje girdeti jo laivyno kanonada (Anderson E. Die baltische Frage und die internationale Politik, S. 334-335). 
akciją prieš bolševizmą, kad ir užimti Petrogradą ${ }^{61}$. Britų kariškių nuomone, derèjo labiau pasikliauti pabaltijiečių jègomis. Pats D. Britanijos kariuomenès generalinio štabo viršininkas feldmaršalas Henris Wilsonas pritarẻ sumanymui šiais tikslais ị Baltijos šalis siųsti karinę misiją, paremti jas karo priemonemis ir patarimais. Sumanymas sèkmingai galejjo būti ịgyvendintas dèl to, kad apie tai tuo metu mąstẻ ir aukščiausi šalies politikai: balandžio 16 d. D. Britanijos premjeras Davidas Lloydas Georgas iškèlè vadinamojo „sanitarinio kordono“ idejją ir pabrèžè būtinybę organizuoti ir aprūpinti nuo Baltijos iki Juodosios jūros vietos pajègas, siekiant „sulaikyti lavos veržimąsi““62. Tuo metu Paryžiuje Antantès Aukščiausioji Taryba, vèlgi daugiausia britų iniciatyva, ịkūrè tarpsąjunginę Baltijos reikalų komisiją, turèjusią tirti pabaltijiečių problemas ir patarinèti aukščiausiems Antantès vadovams per Taikos konferenciją.

Gegužès pradžioje D. Britanijos karo ministerija jau buvo savarankiškai nusprendusi siųsti ị Baltijos regioną karinę komisiją, vadovaujamą generolo Huberto Gougho ${ }^{63}$. Pirmosios jo veiklos instrukcijos iš esmès buvo susijusios su situacija Suomijoje ir Karelijoje. Tačiau minètoji Baltijos komisija jau pirmame savo posėdyje gegužès $14 \mathrm{~d}$. nutarè ten siųsti analogišką komisiją, o gegužès $23 \mathrm{~d}$. Antantès šalių užsienio ministrų konferencija tam pritaré ${ }^{64}$. Taip pamažu èmé formuotis politinè valia, kad gen. H. Goughas atstovautų ne tik D. Britanijos, bet ir visos Antantès interesams. Tuo metu Sajungininkams lyg tyčia kilo dar viena dilema - kaip žiūrèti ị suižūuejjusius R. von der Goltzo vokiečius? Majoras A. Keenanas asmeniškai informavo Baltijos komisiją apie padètị Latvijo$\mathrm{je}^{65}$. Taip i gen. H. Gougho instrukcijas birželio $4 \mathrm{~d}$. buvo ịtraukta naujų

\footnotetext{
61 Anderson E. Die baltische Frage und die internationale Politik, S. 349-350.

62 Ten pat, p. 350.

63 Hovi O. The Baltic Area in british Policy, 1918-1921. Helsinki, 1980, p. 145. Vokiečių istorikas W. Lenzas rašo, jog jau $1918 \mathrm{~m}$. pabaigoje britai buvo pradèję svarstyti idejją $\mathfrak{i}$ Baltijos kraštus pasiųsti D. Britanijos generolą. Tai pasiuntiniui V. Bosanquetui pasiūlè Latvijos premjeras K. Ulmanis, pirmiausia siekdamas ịveikti latvių ir vokiečių priešiškumą (Lenz W. Zur britischen Politik gegenüber den baltischen Deutschen 1918/19, S. 276). Palaipsniui, kaip matyti, šią idèją britai vis labiau plètojo.

64 Hovi O. The Baltic Area in British Policy, p. 145.

65 Anderson E. Die baltische Frage und die internationale Politik, S. 354.
} 
punktų, susijusių su vokiečių evakuacija ${ }^{66}$. Jis oficialiai èmè atstovauti visiems Sąungininkams ir kartu èjo D. Britanijos karinès misijos Baltijos šalyse ir Suomijoje vadovo pareigas. Gen. H. Goughą, prieš išvykstant ł misiją, asmeniškai prième ir instruktavo D. Britanijos karo ministras Winstonas Churchillis, itin ryžtingų, bekompromisių veiksmų bolševikų atžvilgiu šalininkas. Jis manė, jog visos karinès ir diplomatinès priemonès turètų padèti nuslopinti bolševizmą ir visiškai sunaikinti ji pirminiame židinyje - Rusijoje. Todèl ir gen. H. Goughas buvo instruktuojamas laikantis būtent šios radikalios linijos ${ }^{67}$. Paskirtąji misijos vadovą prieš išvykimą prièmé taip pat ir lordas Georgas Curzonas, tuo metu pavaduojantis Paryžiuje buvusị užsienio reikalų ministrą Arthurą Balfourą. Curzonas patarè gen. H. Goughui veikti atsargiau, papasakojo apie riziką, ịspejjo, jog būsima nebolševikinẻ Rusijos vyriausybė galinti priešiškai žiūrèti ị D. Britaniją, jei pastaroji pernelyg išplètotų intervenciją ir, pvz., užsienio jejgoms padètų užimti Petrogradą ${ }^{68}$.

Admirolo W. Cowano laivu gen. H. Gougho misija gegužès 24 d. pasiekẻ Revelị (Taliną) ${ }^{69}$, o gegužès 26 d. atvyko ị Helsinkị ir čia ịkūrè pagrindinị savo misijos štabą ${ }^{70}$ Šią misiją sudarė 72 nariai, visi britai, tik vienas prancūzas prisijungè prie jų jau Helsinkyje ${ }^{71}$. Pats gen. H. Goughas buvo ryžtingų ir principingų veiksmų šalininkas, todèl greitai rado bendrą kalbą su tokių pat pažiūrų admirolu W. Cowanu. Jis nelabai mėgo „baltųjų“ rusų ir prijautė Baltijos šalių judejjimams dèl nepriklausomybès.

Tuo metu britai Baltijos erdvèje formavo dar vieną misiją. Gegužès $26 \mathrm{~d}$. S. Tallentsas buvo paskirtas diplomatinès ir ükinès misijos vadovu ${ }^{72}$.

\footnotetext{
66 Hovi O. The Baltic Area in British Policy, p. 146.

67 Штейнберг В. Джентельмены в Латвии (1917-1920), Рига, 1983, с. 121-122. V. Šteinbergas, aprašydamas H. Gougho susitikimą su W. Churchilliu, pateikia plačią citatą iš paties H. Gougho atsiminimų knygos „Soldiering on“.

68 Ten pat, p. 121. Anderson E. Die baltische Frage und die internationale Politik, S. 353.

69 Anderson E. Die baltische Frage und die internationale Politik, S. 353.

70 Hovi O. The Baltic Area in British Policy, p. 146.

71 Ten pat.

72 S. Tallentso paskyrimą gegužès $26 \mathrm{~d}$. mini tiek lietuvių autoriai (Čepènas P. Naujųjų laikų Lietuvos istorija, p. 483; Gaigalaitè A. Lietuva Paryžiuje 1919 metais, p. 122), tiek E. Andersonas (Anderson E. Die baltische Frage und die internationale Politik, S. 354). O. Hovi rašo, jog gegužès $26 \mathrm{~d}$. S. Tallentsas gavo veiklos instrukcijas (Hovi O. The Baltic Area in British Policy, p. 146).
} 
Tai buvo daroma D. Britanijos užsienio reikalų ministerijos iniciatyva. Santykiai su gen. H. Goughu ir jo misija instrukcijose buvo apibrěžti taip, kad S. Tallentsas, kaip kariškis, kariniais klausimais buvo H. Gougho žinioje, o politiniais klausimais - visiškai nepriklausomas ir turejjo iniciatyvos teisę, bet kartu jam buvo pavesta šiais klausimais patarinèti gen. H. Goughui ir jo misijai ${ }^{73}$. Majoras A. Keenanas pagal naują reglamentą turejo veikti kaip $\mathrm{H}$. Gougho misijos narys. Kaune, atrodo, turèta informacijos apie naujus britų pasiuntinius ị Baltijos erdvę, bet ši informacija buvo bendro pobūdžio ir gana miglota. Štai oficioze „Lietuva“ gegužès 23 d. pasirodè pranešimas, kad padèties tirti „šiomis dienomis“ i Kauną atvyks „nuolatinè anglų valdžios komisija“74. O iš tikrųjų „šios dienos“ tapo keliais mènesiais.

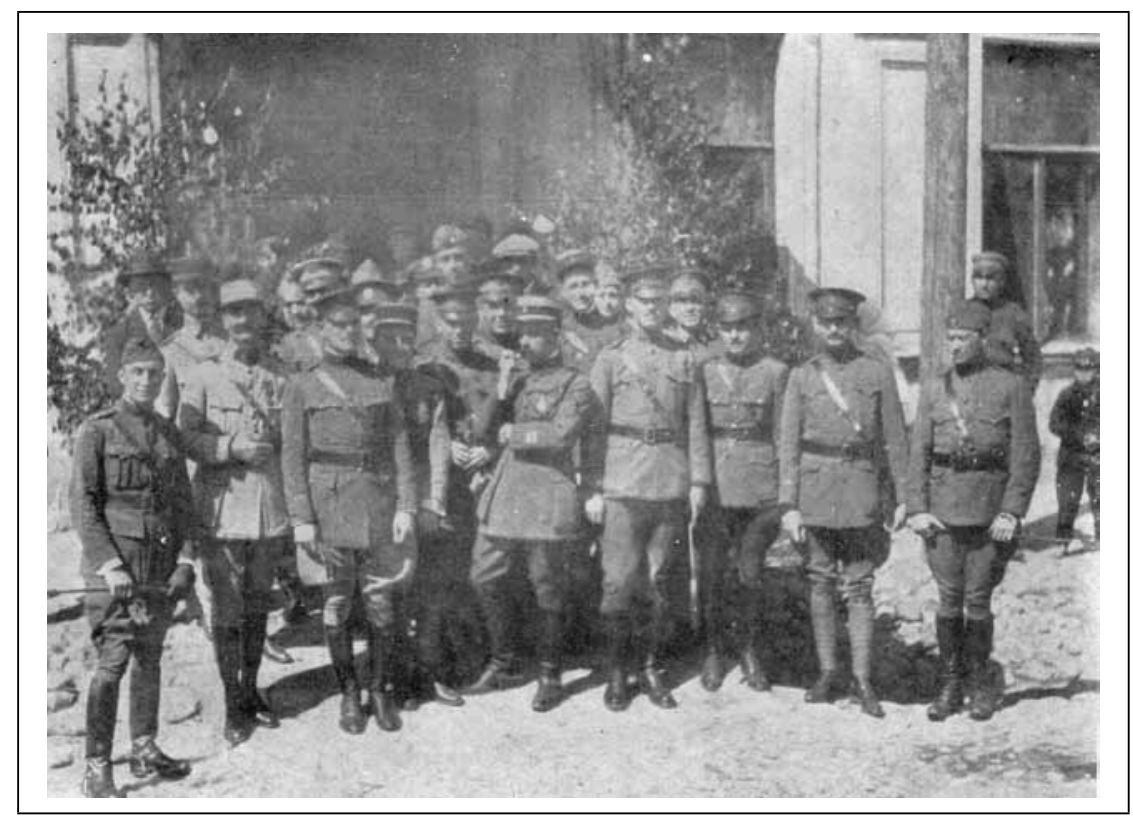

Santarvininkų komisija Lietuvoje 1919 m. //Lietuvos kariuomené 1919 m., p. 154

73 Anderson E. Die baltische Frage und die internationale Politik, S. 354.

74 Politikos žinios. Nuolatinė Anglų Valdžios Komisija atvažiuoja ị Kauną // Lietuva, 1919, Nr. 109, p. 3. 
M. Sleževičiaus vyriausybę vis dar kamavo sunkiai sprendžiamos materialinio aprūpinimo ir apskritai krašto ekonomikos atkūrimo problemos. Gegužès $26 \mathrm{~d}$. kabineto posėdyje prekybos ir pramonès ministras J. Šimkus buvo paskirtas vadovauti šioms problemoms spręsti sudarytai delegacijai, turëjusiai vykti $\mathfrak{i}$ Paryžių (po to $-\mathfrak{i}$ Londoną) $)^{75}$. Ten vedantis kelias ir vèl ejo tik per Liepoją. Norint atskleisti šio punkto reikšmę tuometei Lietuvai ir parodyti, kokios atkaklios buvo lietuvių pastangos ji turèti, turbūt reikètų šiek tiek nukrypti ị šali.

Neperdedant galima teigti, jog Liepoja Lietuvai $1919 \mathrm{~m}$. buvo ne tik igeidžio tapti jūrine valstybe objektas, bet tiesiogine šio žodžio prasme

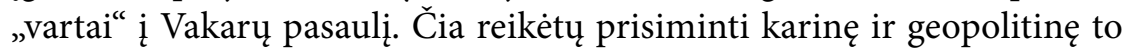
meto Lietuvos situaciją: valstybès branduolys Kaune egzistavo karo ar bent jau konflikto su ịvairiomis vokiečių, rusų, lenkų jègomis, atstovaujančiomis šių artimiausių Lietuvos kaimynių interesams, sąlygomis. Vadinasi, susisiekimas, ryšiai su tolimesniu užsieniu per šias valstybes buvo jei ne neįmanomi, tai bent jau labai problemiški. Kiek daugiau vilčių teikianti atrodè tik kryptis per Latviją, ypač vandens keliu per artimiausią Lietuvai jos uostą Liepoją. Tad natūraliai i ją ir nukrypo Lietuvos politikų dẻmesys. 1919 m. gegužę Lietuvos vyriausybe pažymèjo, jog 90 \% Lietuvos užsienio prekybos vyksta būtent per Liepoją ${ }^{76}$. Tačiau visi ryšiai su išoriniu pasauliu per Liepoją, kaip ir apskritai visas susisiekimas vandens keliu per Baltijos jūrą, buvo britų rankose. D. Britanijos karo laivynas karo metu vykdè Vokietijos jūrų blokadą. 1918 m. lapkriț sudarius paliaubas britų laivynas Baltijoje tęsè blokadą tuo pretekstu, jog galutinè taika su Vokietija dar nepasirašyta. Tačiau tuo dangstantis pirmiausia ir nuolat buvo blokuojami bolševikų kontroliuojami uostai ir pakrantès. O vokiečių, ịsitvirtinusių rytinèje Baltijos pakrantèje, veiksmai buvo diferencijuojami. 1918-1919 m. žiemą, kai britai kovoje su bolševikais rèmé vokiečių igulą Liepojoje, jie kartu garantavo bent minimalias galimybes palaikyti civilinius ryšius per Liepoją. Tačiau padidèjus vokiečių priešiškumui ir ambicijoms, Antantè ir šią pakrantę 1919 m. kovo 3 d. ịtraukè ì laivybai draudžiamą zoną ${ }^{77}$. Amerikiečiai, pirmiausia Herberto Hooverio

\footnotetext{
19190526 Lietuvos vyriausybès posėdžio protokolas. LCVA, f. 923, ap. 1, b. 24, 1. 59.

76 Butkus Z. Lietuvos ir Latvijos santykiai 1919-1929 metais, p. 19.

77 Anderson E. Die baltische Frage und die internationale Politik, S. 343.
} 
vadovaujama pagalbos organizacija, nebuvo tuo patenkinti, nes šią priemonę vertino kaip britų sieki šioje erdvejje igyti ūkini monopolị. Todèl JAV atstovai iki balandžio $7 \mathrm{~d}$. išsireikalavo bent iš dalies atšaukti blo$\mathrm{kadąq}^{78}$. Visa ši besikeičianti konjunktūra, be abejonès, smarkiai palietè ir interesus. Pvz., 1919 m. birželio 11 d. Lietuvos (tuo metu Antantès santykiai su vokiečiais ypač paaštrèjo) Lietuvos prekybos ir pramonès ministerija kreipèsi į užsienio reikalų ministeriją skųsdamasi, jog Lietuvai skirti kroviniai Baltijoje vèl blokuojami, ir prašè imtis žygių, kad britų ir amerikiečių valdžios šios blokados netaikytų 79 . Dokumento rezoliucijoje parašyta, jog šiuo klausimu taip pat reikètų kreiptis ị D. Britanijos atstovą S. Tallentsą.

Ne mažiau už krovinių judejjimą per Liepoją svarbus Lietuvai klausimas buvo valdžios pasiuntinybių ir delegacijų vykimo per ši bent iš dalies Antantès žinioje esanti punktą galimybe jau vien dèl to, kad tuo metu Paryžiaus taikos konferencijoje dalyvavo lietuvių delegacija, o saugiausias ir patikimiausias susisiekimo kelias ị ji èjo būtent per Liepoją. 1919 m. gegužès 30 d. M. Sleževičiaus vyriausybė ten pasiuntė Lietuvos kariuomenès artilerijos dalies viršininko M. Gedgaudo vadovaujamą kariškių delegaciją, kurios tikslas buvo gauti ginklų, šaudmenų, kitos karinès amunicijos ir kartu pasirūpinti karininkų ir kito karinio personalo $\mathfrak{i}$ Lietuvos kariuomenę verbavimu, finansavimu ir kt. ${ }^{80}$ Ji turèjo užmegzti ryšius su Antantès šalių kariniais atstovais Paryžiuje ir JAV lietuviais. Ši delegacija ị Paryžių vyko per Liepoją ${ }^{81}$.

Tuo metu J. Šimkus gegužès 31 d. susitiko su net ir vokiečių savivalès sąlygomis nuolat reziduojančiu H. Grantu Watsonu, kuris pasakè, kad „apie 4-5 birželio atvažiuoja ị Liepoją vyriausias komisaras, anglų paskirtas prie Baltijos valstybių p. Tallents, kuris turès rišti visus klausimus (taip pat ir paskolos klausimus) ${ }^{\text {“82 }}$. Jis J. Šimkui pasiūlè pasilikti ir pa-

78 Ten pat.

7919190611 Lietuvos prekybos ir pramonès ministerijos raštas URM. LCVA, f. 383, ap. 7, b. $53,1.179$.

${ }^{80}$ Gaigalaitè A. Lietuva Paryžiuje 1919 metais, p. 137.

${ }^{81}$ Karininko M. Gedgaudo, vadovavusio delegacijai, buvimo Liepojoje 1919 m. gegužès paskutinèmis dienomis faktą savo pranešime ị Kauną patvirtino ministras J. Šimkus (J. Šimkaus 19190601 pranešimas M. Sleževičiui iš Liepojos. LCVA, f. 383, ap. 7, b. 38, 1. 111).

${ }^{82}$ Ten pat, 1. 110. 
laukti S. Tallentso. Kadangi J. Šimkus jau buvo susitvarkęs kelionès dokumentus (per Antantès pasiuntinius Liepojoje) ${ }^{83}$ ir turëjo vykti ị Paryžių, M. Sleževičiaus vyriausybé birželio 3 d. specialiai ị št susitikimą Liepojoje pasiuntė J. Vileišs̆ ir Tomą Naruševičių ${ }^{84}$. Bet susitikimas nę̧vyko, o sugrižž birželio $10 \mathrm{~d}$. pasiuntiniai informavo vyriausybę, kad tik birželio $15 \mathrm{~d}$. „atvažiuoja anglų komisija, kuri išriš visus klausimus, paskolos ir ekonominius $^{\text {"85 }}$. Šios informacijos būta labai netikslios ar net klaidingos - matyt, tai lèmé sudètinga situacija Liepojoje ir visoje Latvijoje.

Pirmosiomis birželio dienomis S. Tallentsas D. Britanijos karo laivu vis dèlto atplauke ị Liepoją, tačiau apsistoti Latvijoje dèl vokiečių veiklos jam buvo sunku ${ }^{86}$. Vokiečiai šeimininkavo ne tik Liepojoje - iš bolševikų atkovotoje Rygoje jie pradèjo masiškai terorizuoti gyventojus ${ }^{87}$, grasino ir Antantės pasiuntiniams, kurie saugiai jautèsi tik savo laivuose ${ }^{88}$. Sąjungininku misijos dèmesị sutelkè ị padètị Rygoje. S. Tallentsas irgi norèjo vykti ị Rygą, $\mathrm{o}$ iš ten $-\mathfrak{i}$ Kauną, bet vokiečiai neleido ${ }^{89}$. Tik JAV misijai (kuria vokiečiai labiau pasitikejjo) padedant jam pavyko apsilankyti Rygoje. Iš ten jis išvy-

8319190601 Lietuvos vyriausybès posedžio protokolas. LCVA, f. 923, ap. 1, b. 24, 1. 47.

${ }^{84}$ Ten pat. Pats J. Šimkus prašè vyriausybès , apie birželio $5 \mathrm{~d}$.“ “ $\mathfrak{i}$ Liepoją vietoj jo pasiųsti J. Vileiši kalbètis su atvykstančiais britais („Pabaltijo komisija“).

${ }^{85} 19190610$ Lietuvos vyriausybès posèdžio protokolas. LCVA, f. 923, ap. 1, b. 24, 1. 36 ap.

86 Штейнберг В. Джентельмены в Латвии (1917-1920), Рига, 1983, с. 110-115. V. Šteinbergas smulkiai atpasakoja ir ištisai cituoja S. Tallentso atsiminimų knygos „Man and Boy" turinị. Kad S. Tallentsas 1919 m. birželio pradžioje vis dèlto apsilankẻ Liepojoje, liudija ir mūsų aptiktas archyvinis dokumentas: $1919 \mathrm{~m}$. birželio $8 \mathrm{~d}$. būtent iš Liepojos S. Tallentsas atsiliepe ị M. Sleževičiaus raštą britams (LCVA, f. 383, ap. 7, b. 53, 1. 180).

87 Vokiečių pajègų terorą Rygoje plačiai savo atsiminimuose aprašo S. Tallentsas (Штейнберг В. Джентельмены в Латвии, с. 110-115).

${ }_{88} 1919$ m. birželio 8-9 d. vokiečiu pajègos grasino ị Latvijos pakrantes atplaukusiam britų eskadriniam minininkui „Waterhen“ (Anderson E. Die baltische Frage und die internationale Politik, S. 357). Labai ịtemptą, nepaprastą padètį, kurią buvo sunku numatyti iš anksto (turint omenyje pranešimus, matyt, iš tolimojo Londono dèl datų, kai Latvijoje turejjo pasirodyti nauji britų atstovai), rodè ir, pvz., tai, kad tą pačią birželio $8 \mathrm{~d}$. ị vieną lietuvių politinị raštą atsiliepe ne kuris nors specialią užduotị turẻęę britų misijos narys, o tiesiog laivyno karininkas (laivo „Rojalist“ komandoras Duffas) (LCVA, f. 383, ap. 7, b. 53, 1. 181-182).

89 В. Штейнберг. Джентельмены в Латвии, с. 114. 
Didžiosios Britanijos karinis diplomatinis atstovavimas Lietuvoje iki valstybingumo pripažinimo de facto (1918 m. gruodis-1919 m. rugsèjis)

ko ị palyginti saugesni Taliną ${ }^{90}$. Birželio $11 \mathrm{~d}$. S. Tallentsas čia susitiko su gen. H. Goughu ir tarèsi dèl svarbiausių uždavinių sprendimo ${ }^{91}$.

1919 m. birželio antra pusè tapo vokiečių ir Antantès santykių išbandymo laikotarpiu. Buvo neaišku, ar Vokietija pasirašys Versalio taiką, ar neatsinaujins plataus masto karo veiksmai. Tik kai Vokietija pasiraše šią sutartị, o Latvijoje jungtinès latvių ir estų pajègos birželio $22 \mathrm{~d}$. sumušè R. von der Goltzo kariuomenę prie Cèsio, vokiečių ambicijos buvo pažabotos $^{92}$.

Sąjungininkų misijos Baltijos erdvejje ėmė veikti iš esmès laisvai daugelyje sričių. Lietuviai tuo metu savo skundus dèl suaktyvejjusių vokiečių ir lenkų priešiškų veiksmų adresavo S. Tallentsui ị Liepoją ${ }^{93}$, tačiau faktiškai buvo bendraujama su S. Tallentso misijai priskirtu, jam atstovaujančiu ir ji pavaduojančiu H. Grantu Watsonu ${ }^{94}$. Pats S. Tallentsas liepos 3-8 d., vokiečiams pasitraukus, èjo Rygos civilinio gubernatoriaus pareigas $^{95}$.

1919 m. vasarą Lietuvos padėtis vis dar buvo sudètinga. Situaciją komplikavo tuo metu labai paaštrèję santykiai su Lenkija, jos kariuomenès veržimasis ị Lietuvos žemes, Antantės atstovų nustatytos demarkacijos linijos nepaisymas. Vyriausybès pasiųstas ị Liepoją liepos $12 \mathrm{~d}$. vèl atvyko J. Šimkus, kuris čia rado tik H. Grantą Watsoną, nes kitos Sąjungininkų pasiuntinybès jau buvo persikrausčiusios ị Rygą, kur kūrèsi nepriklauso-

90 Ten pat, p. 115.

91 Anderson E. Die baltische Frage und die internationale Politik, S. 357.

92 Ten pat, p. 350-352; 357-360. Lietuvių istoriografijoje apie vokiečių veiklą Latvijoje ir jos pasienyje su Lietuva 1919 m. iki kovų su bermontininkais žr.: Lesčius V. Lietuvos kariuomenè Nepriklausomybès kovose 1918-1920, Vilnius, 2004, p. 194-202; Ališauskas K. Kovos dèl Lietuvos nepriklausomybès, p. 339-356; išsamiai žr.: Birontas A. Bermontininkams Lietuvą užpuolus, Kaunas, 1934. Daug įdomių faktų yra ir atsiminimų literatūroje, pvz., žr.: Bielinis K. Gana to jungo, Niujorkas, 1971.

93 Pvz.: 19190707 lietuvių raštas S. Tallentsui ị Liepoją dèl prasidejusio lenkų veržimosi ị Lietuvą. LCVA, f. 383, ap. 7, b. 53, 1. 1; 19190622 lietuvių raštas S. Tallentsui dèl vokiečių elgesio Šiauliuose. LCVA, f. 383, ap 7, b. 53, 1. 165-166.

94 Pvz.: 19190617 Watsono atsakymas ị19 0521 M. Sleževičiaus telegramą dèl rusų belaisvių. LCVA, f. 383, ap. 7, b. 53, 1. 175; 19190602 Watsono pranešimas M. Sleževičiui dèl S. Tallentso atvykimo. LCVA, f. 383, ap. 7, b. 53, 1. 187 (pranešime tiksli atvykimo data nenurodyta).

95 Anderson E. Die baltische Frage und die internationale Politik, S. 359. 
mos Latvijos valdžios institucijos ${ }^{96}$. Per Watsoną informavęs Londoną apie lenkų veiksmus Lietuvoje, J. Šimkus irgi išvyko ị Rygą. Jis čia susitiko su „anglų misijos šefu“. Pastarasis patikino J. Šimkų, jog „klausimas dèl davimo mums paskolos anglų vyriausybės jau nuspręstas, visos kliūtys išeina iš to, kad Anglija negalinti daryti separatinių žingsnių. Lygiai taip pat išrištas klausimas davimo mums ginklų - visa dabar pareina nuo Paryžiaus s"97. J. Šimkus apie tai informavo jau grị̌ęs, liepos 19 d. vyriausybès posèdyje.

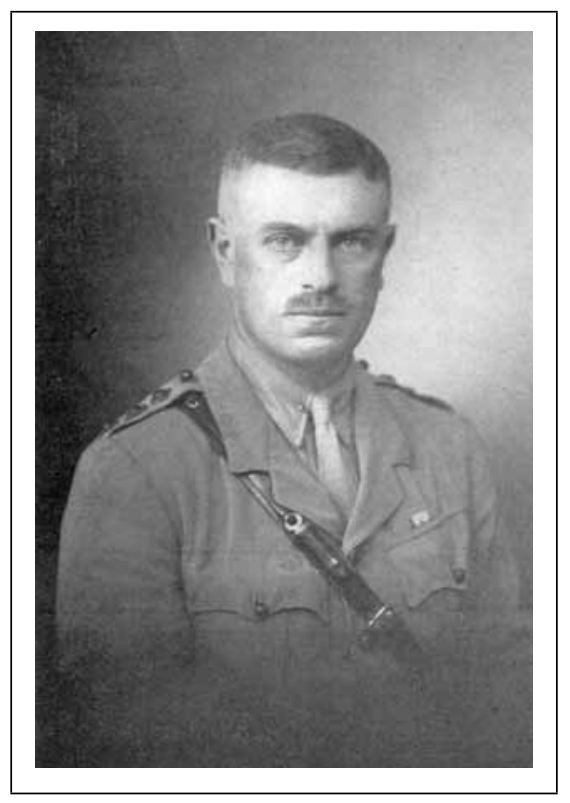

Didžiosios Britanijos atstovas Lietuvoje kpt. G. Brodis // Lietuvos kariuomene 1919 m., p. 156.
Be to, jo žodžiais, „paaiškinus man dabartinę Lietuvos padèti, man esant buvo sustatyta telegrama dèl davimo mums ginklu ir vieno milijono svarų sterlingu avanso paskolos sąskaiton ${ }^{\text {“98. }}$. Su J. Šimkumi iš Rygos ị Kauną atvažiavo ir S. Tallentso misijos narys kapitonas G. Brodis ${ }^{99}$, paskirtas ì misiją dirbti komercijos srity$\mathrm{je}^{100}$. Tačiau čia atvykęs jis èmè aktyviai tarpininkauti lietuviu ir lenku konflikto metu. Tik po kurio laiko Lietuvos atstovai išsiaiškino, kad to daryti jis nebuvo igaliotas ir veikè savo iniciatyva, o per galimą sèkmingą tarpininkavimą siekè asmeninès karjeros, jei, pasak paties Brodžio, „nesutaikoma būtų sutaikinta ${ }^{\text {"101 }}$.

\footnotetext{
96 J. Šimkaus pranešimas 19190719 Lietuvos vyriausybès posèdyje. LCVA, f. 923, ap. 1, b. $57,1.37$.

97 Ten pat, 1. 37 ap.

98 Ten pat.

99 Kauno kronika // Lietuva, 1919, Nr. 156, p. 5.

${ }^{100}$ Gruzdienė E. Užsienio valstybių karinès misijos pirmojoje Lietuvos Respublikoje 1919-1920 m., daktaro disertacija, p. 182.

${ }^{101} 1919$ m. rugpjūčio 12 d. karininko L. Natkevičiaus pranešimas iš Rygos Lietuvos ministrui pirmininkui. LCVA, f. 923, ap. 1, b. 39, 1. 35.
} 
Brodžio veikla Lietuvoje liepos pabaigoje-rugpjūčio pradžioje nebuvo sèkminga. H. Gougho karinès misijos nariai Rygoje, sužinoję apie ją, nebuvo patenkinti jau vien dèl to, kad Brodis ịsibrovè ị jų kompetencijos sritị $^{102}$. Be to, G. Brodis siųsdavo nešifruotas telegramas apie lenkų veiklą Lietuvoje, o jas perimdavo vokiečių radijo stotis. Vokiečiai tai tuoj pamėgino panaudoti savo interesams: D. Britanijos misijai Rygoje nusiuntè argumentuotą pranešimą, jog greitai negali pasitraukti iš savo pozicijų, nes lenkų veikla Lietuvoje kelia grèsmę ne tik lietuviams, bet ir pačiai Vokietijai ${ }^{103}$. Po viso to $\mathrm{H}$. Grantas Watsonas pasistengè G. Brodi greitai atšaukti iš Kauno (paties S. Tallentso tuo metu Rygoje nebuvo) ${ }^{104}$. Tačiau žalos G. Brodžio veikla lietuvių interesams vis dèlto nepadaré ${ }^{105}$.

Jau siunčiant britų misijas ị Baltijos erdvę buvo numatyta, kad jos turès savo atskirus skyrius visose iš naujo besikuriančiose valstybėse. Suomijoje ir Estijoje tai padaryti buvo paprasčiausia, sutramdžius vokiečius tokia galimybe atsirado pirmiausia Latvijoje, o po to ir Lietuvoje. Pats gen. H. Goughas atvyko ị Latviją, o vadovauti jo misijos Rygos skyriui buvo pavesta generolui Alfredui Burtui. Lietuvos valdžia ryšiams su britų misija palaikyti į Rygą pasiuntẻ karininką Ladą Natkevičių ${ }^{106}$. Dar J. Šimkaus apsilankymo Latvijoje liepos mèn. metu lietuviai buvo informuoti apie būsimą atskiros britų karinès misijos ị Lietuvą atsiuntimą.

Rugpjūčio 15 d. M. Sleževičiaus vyriausybè vèl grị̌zo prie santykių su D. Britanija svarstymo ir tam skyrè visą posėdį ${ }^{107}$. Svarstymą galbūt

\footnotetext{
102 Ten pat.

${ }^{103}$ Ten pat, p. 35-35 ap.

104 Ten pat, p. 35.
}

${ }^{105}$ Taip teigè karininkas L. Natkevičius. Lietuvių visuomenès ir politikos veikejjas Kipras Bielinis savo atsiminimuose mini, jog kapitonas Brodis 1919 m. lapkriti su pulkininku Dosse stebejo vokiečiu ir bermontininkų evakuaciją Šiauliuose. Beje, apie kapitoną Brodị K. Bielinis rašo ir taip: „Šiauliuose <...>kažkas paaiškino, kad kap. Brodie joks anglas; jo tikroji pavardè Brodskis, kilęs iš Ukrainos, kur Brodskiams priklausę cukraus fabrikai“ (Bielinis K. Gana to jungo, p. 433). Čia jis mini, kad Brodis mokèjęs rusų kalbą. Kapitonas G. Brodis 1919 m. liepą atvykęs ị Kauną, čia, pasak oficiozo „Lietuva“, netgi turèjo atidaręs savo biurą, kur priiminėjo interesantus (Kauno kronika // Lietuva, 1919, Nr. 161, p. 3).

${ }^{106}$ Karininkas L. Natkevičius iš pradžių buvo deleguotas ị Rygą neoficialiai, tik nuo 1919 m. rugpjūčio 12 d. jis tapo oficialiu kariniu atstovu. Žr.: 19190812 Lietuvos vyriausybės posedžio protokolas. LCVA, f. 923, ap. 1, b. 57, 1. 67.

10719190815 Lietuvos vyriausybès posèdžio protokolas. LCVA, f. 923, ap. 1, b. 57, 1. $73-75$ ap. 
inspiravo ir L. Natkevičiaus rugpjūčio $12 \mathrm{~d}$. platus pranešimas iš Rygos premjerui. L. Natkevičius pranešè apie savo pokalbius su H. Grantu Watsonu, kuris pareiškęs, kad „pripažinimas Lietuvos nepriklausomybės yra dalykas tikras ir greitu laiku tai turi būti padaryta de jure ir de facto" ${ }^{\text {"108. }}$. Taip pat gen. A. Burtas pasakęs, jog jie, kariškiai, „yra gavę telegramų iš Londono ir Paryžiaus, kuriose pasakyta, kad Lietuvos klausimu ir jos kariuomenés apginklavimu neatidèliojant pradedama rūpintis, kas ir yra

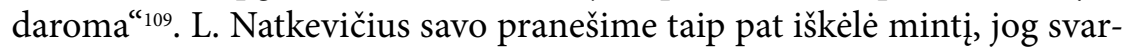
bu suinteresuoti britus ekonominiu Lietuvos patrauklumu.

Taigi rugpjūčio $15 \mathrm{~d}$. premjeras vèl iškèlè britų protektorato Lietuvai reikšmingumo klausimą. Jis atkreipe dèmesị ị neišvengiamą būtinybę šioje situacijoje remtis kuria nors didvalstybe ir argumentuotai ịrodinëjo, kad Anglija tam labiausiai tinkanti ${ }^{110}$. Ji palaikančių kabineto narių entuziazmą, matyt, skatino ir J. Šimkaus pastaba, jog jo vizito Rygoje metu S. Tallentsas pasakęs, kad vokiečiams atsitraukus britų kariuomenè užimsianti Klaipèdos uostą ir vèliau perduosianti jị lietuviams ${ }^{111}$. Svarstant santykių su britais visuma „skilo“ $\mathfrak{i}$ du atskirus klausimus: dèl protektorato apskritai reikalingumo ir dèl koncesijų britams siūlymo Lietuvos geležinkelių, telegrafo linijų, Klaipedos uosto ir Nemuno eksploatavimo srityse. Ministras Steponas Kairys diskusijose iškèlè mintį, jog „susirišę su Anglija ekonominiai, tuo pat pripažinsime protektoratą "112. Svarstymo išdavos rodè, kad ši idèja tyliu kabineto narių sutarimu lyg ir tapo tam tikra tolesnès veiklos gaire: apsistota ties koncesijų detalių nagrinèjimu manant, jog jos ir sudaro protektorato turinị. Vis dèlto dèl abiejų klausimų buvo balsuojama atskirai. Balsuojant paaiškejjo, jog kairieji kabineto nariai ir premjeras yra už protektoratą ir koncesijas, o dešinieji, taip pat ir J. Vileišis, nusiteikę skeptiškai ir kritiškai. Būtent J. Vileišis buvo kategoriškai nusistatęs prieš koncesijas britams. Jis ši klausimą prilygino buvusiam koncesijų vokiečiams klausimui ir pabrèžè, kad tokios svarbos klausimai priklausantys tik Stei-

\footnotetext{
1081919 m. rugpjūčio 12 d. karininko L. Natkevičiaus pranešimas iš Rygos Lietuvos ministrui pirmininkui. LCVA, f. 923, ap. 1, b. 39, 1. 34.

109 Ten pat, 1. 34 a. p.

${ }^{110} 19190815$ Lietuvos vyriausybès posèdžio protokolas. LCVA, f. 923, ap. 1, b. 57, 1. 74.

111 Ten pat, 1.73 a. p. -74 .

112 Ten pat, 1.73 a. p.
} 
Didžiosios Britanijos karinis diplomatinis atstovavimas Lietuvoje iki valstybingumo pripažinimo de facto (1918 m. gruodis-1919 m. rugsèjis)

giamojo Seimo kompetencijai ${ }^{113}$. Premjeras jam pateike kontrargumentų, jog „buvo kalbèta, kad mes be Steigiamojo Seimo neturime teisès daryti tokio svarbaus žingsnio, kad visuomenė gali pasmerkti mūsų darbus, bet ką pasakys ta pati visuomenè, jeigu Steig. Seimo niekad nebus, jeigu mūsų šali pagrobs priešai pirmiau, negu mes sušauksime Steig. Seimą "114. Svarstant šị klausimą didelę reikšmę turèjo ir tai, kad šiame kabineto posėdyje aktyviai dalyvavo iš Londono parvykęs vyriausybès igaliotinis V. Čepinskis, kuris aiškiai buvo pareiškęs, kad protektoratas reikalingas.

Jau rugpjūčio $13 \mathrm{~d}$. vyriausybė pradejo rengti ir rugpjūčio $16 \mathrm{~d}$. išsiuntė nemažai raštų britų misijoms Rygoje. Rašte, adresuotame H. Grantui Watsonui, dèkojama „už ekonominès komisijos Lietuvai paskyrimą"115, o rašte gen. H. Goughui - „už paskyrimą karo misijos Lietuvai su pulkininku Robinsonu priešakyje "116. Kitame rašte H. Goughui prašoma instruktorių Lietuvos kariuomenei, ,jos karo reikalams pagerinti: 1. generalinio štabo 3 asmenų, kurių vienas žinotų žvalgybos ir kontržvalgybos reikalus; 2.1 inžinieriaus automobilių daliai ir 2 technikų; 3. po vieną artileristą, péstininką ir intendantūros dalies "117, padaryti viską, kad D. Britanijos vyriausybė juos atsiųstų. Kiti britams skirti dokumentai daugiausia buvo susiję su nusiskundimais lenkų ir vokiečių elgesiu Lietuvoje ${ }^{118}$.

Rugpjūčio 19-20 d. ị raštus, adresuotus H. Grantui Watsonui, atsiliepé jau pats S. Tallentsas ${ }^{119}$. Atsakydamas ị lietuvių padèką dẻl ekonominès komisijos skyrimo, jis kartu informavo, kad jau rugpjūčio 24 d. ị Kauną išvyksta plk. R. B. Wardo (Ward Richard Barrington) vadovaujama misija ${ }^{120}$.

\footnotetext{
113 Ten pat, 1. 74 .

114 Ten pat.

11519190816 Lietuvos vyriausybès raštas Grantui Watsonui. LCVA, f. 383, ap. 7, b. 53, 1. 61; juodraštis, datuotas 19190813 - 1. 50-50 a. p.

${ }^{116} 19190816$ Lietuvos vyriausybès raštas H. Goughui. LCVA, f. 383, ap. 7, b. 53, 1. 55-56; juodraštis, datuotas 19190813 - 1. 51-52.

11719190816 Lietuvos vyriausybès raštas H. Goughui dèl instruktorių skyrimo. LCVA, f. 383, ap. 7, b. 53, 1. 62; juodraštis, datuotas $19190813-1.48$.

118 Pvz., 19190816 Lietuvos vyriausybès raštas H. Goughui dèl Virgoličiaus veiklos Kuršènuose. LCVA, f. 383, ap. 7, b. 53, 1. 59-60; juodraštis, datuotas 19190813 - 1. 53-54.

11919190819 S. Tallentso atsakymas ị lietuvių raštą dèl finansinès paskolos. LCVA, f. 383, ap. 7, b. 53, 1. 63; 19190819 S. Tallentso atsakymas ị lietuvių skundą dèl lenkų elgesio. LCVA, f. 383, ap. 7, b. 53, 1. 65.

${ }^{120} 19190820 \mathrm{~S}$. Tallentso atsakymas ì lietuvių padèkos raštą dèl ekonominès komisijos paskyrimo. LCVA, f. 383, ap. 7, b. 53, 1. 67.
} 


\section{BRITANIJOS ATSTOVYBIŲ İSIKŪRIMAS LIETUVOS TERITORIJOJE IR JŲ VEIKLOS PRADŽIA}

Lietuvai visą laiką ypač svarbi buvo ekonominė santykių su D. Britanija pusè. Krašto ekonomika galejjo atsigauti tik gavusi užsienio valstybių paskolą. Lietuva dar tik siekè Antantès valstybių pripažinimo, o D. Britanijos bankai, ị kuriuos buvo kreiptasi, dvejojo, ar verta suteikti dar nepripažintai valstybei tokią paskolą. Dèl to Lietuvos valdžia buvo ypač suinteresuota palaikyti nuolatinius ryšius su ekonomikos problemas išspręsti galinčia padèti S. Tallentso misija ir, kiek įmanoma, pati rodė iniciatyvą, siekdama juos palaikyti.

Kaip minèta, jau nuo 1919 m. gegužès buvo žinoma apie D. Britanijos pasiuntinybės Lietuvai sudarymą, tačiau visiškai nebuvo aišku, kokios bus šios pasiuntinybès kompetencijos sritys ir struktūra. Tačiau pamažu visi šie aspektai ėmė aiškèti per pokalbius su pačiu S. Tallentsu, kuris per labai trumpą laiką susikūrè autoritetingiausio ekonominių klausimų sprendejo ịvaizdị. 1919 m. rugpjūčio 19-20 d., t. y. tomis dienomis, kai atsaké ị lietuvių raštus, adresuotus H. Grantui Watsonui, S. Tallentsas jau pats buvo susiruošęs vykti į Lietuvą, automobiliu nuvažiuoti ne tik ị Kauną, bet ir ¡ kai kurias Šiaurès Lietuvos vietoves ${ }^{121}$. Tačiau šis vizitas neịvyko. Galima manyti, jog tam turèjo ịtakos rugpjūčio $20 \mathrm{~d}$. incidentas Skuode, kur S. Tallentso misijos nariai plk. ltn. R. B. Wardas, kpt. Wesselis ir G. Berry, turejję ištirti, kaip vokiečiai elgiasi su vietos gyventojais, pateko i̇ vokiečiu nelaisvę ir tik po dviejų dienų, kilus triukšmui vos ne tarptautiniu lygiu, buvo atsiprašius paleisti ${ }^{122}$. Misijos būstinejje Rygoje galbūt buvo svarstytas ir toks variantas - kad vietoj misijos vadovo ị Kauną galètų vykti ir kuris nors kitas autoritetingas misijos narys. Mat dar rugpjūčio 19 d. oficiozas „Lietuva“ pranešè, kad ị Lietuvą „rugpjūčio pab. turi atvažiuoti ekonomijos dalykams nuspręsti D. Britanijos komisijos kraštams atstovas anglas W. L. Cozalet'as" ${ }^{\prime 23}$ (taip pat S. Tallentso misijos narys). Tačiau, kaip mi-

${ }^{121}$ Nedatuotas S. Tallentso telegramos J. Šimkui vertimas ị lietuvių k. LCVA, f. 383, ap. 7, b. $53,1.47$.

${ }^{122}$ Gruzdienė E. Užsienio valstybių karinès misijos pirmojoje Lietuvos Respublikoje 1919-1920 m., daktaro disertacija, p. 66.

${ }^{123}$ Politikos žinios. Santarvè ir Lietuva // Lietuva, 1919, Nr. 180, p. 3. 
nèta, jau rugpjūčio 20 d. S. Tallentsas informavo Lietuvos valdžią, jog rugpjūčio 24 d. ị Kauną išvyksta R. B. Wardo vadovaujama misija, kaip bendros S. Tallentso vadovaujamos misijos padalinys (įdomiausia, kad dar tą pačią rugpjūčio 20-ąją R. B. Wardas, kaip minèta, pateko ị vokiečių nelaisvę Skuode). Rugpjūčio 26 d. S. Tallentsas oficialiai patvirtino R. B. Wardo igaliojimus atstovauti misijai Kaune ${ }^{124}$.

Idomu tai, jog S. Tallentso misijos formavimo metu iš pradžių netgi nebuvo nustatyta konkreti padalinių struktūra. Misijos nariai iš $\mathrm{D}$. Britanijos i rytinę Baltijos pakrantę atvyko keliomis grupėmis ir ne vienu metu. D. Britanijos karališkosios aviacijos karininkas R. B. Wardas ${ }^{125}$ S. Tallentso misijos

${ }^{124}$ Oficialus S. Tallentso parengtas R. B. Wardo igaliojimų patvirtinimas Lietuvos valdžiai. LCVA, f. 383 , ap. 7, b. 53, 1.84 .

${ }^{125}$ Karininko ir vèliau diplomatinio pasiuntinio R. B. Wardo biografinis portretas būtų maždaug toks: Wardas Richardas Barringtonas (1882-1933) dar 1895 m. pradejo tarnybą D. Britanijos karališkajame laivyne kadetu, tarnavo įvairiuose laivuose. 1906 m. igijo vokiečių kalbos vertèjo kvalifikaciją. 1907 m. vedè vokietę Ilzę Redelsheimer iš Berlyno, tais pačiais metais pasitraukè iš tarnybos laivyne. $1913 \mathrm{~m}$. vèl grižzo ị tarnybą, $1916 \mathrm{~m}$. ịstojo ị D. Britanijos karališkojo laivyno oro pajègas ir pradejjo aviatoriaus karjerą. $1917 \mathrm{~m}$. liepą buvo pakeltas eskadrilès vadu (squadron commander). Kai $1918 \mathrm{~m}$. balandžio $1 \mathrm{~d}$. èmè kurtis savarankiškos D. Britanijos karališkosios oro pajejgos, iškart perejjo i jas (tada jau turejjo majoro laipsni). S. Tallentso misijos Baltijos šalyse nariu oficialiai tapo $1919 \mathrm{~m}$. birželio $16 \mathrm{~d}$. Su tuo susijęs ir paaukštinimas - jam buvo suteiktas laikinojo pulkininko leitenanto laipsnis. 1919 m. rugpjūčio 27 d. D. Britanijos oro pajègose buvo įvesta kita rangų sistema ir turètas R. B. Wardo laipsnis prilygintas naujajam eskadrilès vado (squadron leader) laipsniui. $1920 \mathrm{~m}$. kovą reorganizavus S. Tallentso misiją, buvo paskirtas D. Britanijos diplomatiniu konsulu Kaune, čia išbuvo iki 1920 m. spalio pabaigos. 1920 m. gruodị pasitraukè iš diplomatinès tarnybos. $1921 \mathrm{~m}$. rugsèji grị̌zo ị aktyvią tarnybą karo aviacijoje, lankè jos vadovybès organizuotus bendradarbiavimo su laivynu ir teritorinès navigacijos kursus. 1923 m. sausi pasiųstas dirbti 1922 m. įsteigto tarptautinio Aeronautikos komiteto D. Britanijos sekcijoje. $1923 \mathrm{~m}$. suteiktas aviacijos Wing Commander rangas (atitinkantis pulkininko leitenanto laipsnị), buvo paskirtas ị aviacijos būrị, atsakingą už pakrančių apsaugą. $1928 \mathrm{~m}$. dèl sveikatos buvo laikinai priverstas nebeskraidyti, perkeltas ị oro pajègu depą Aksbridže (Uxbridge). Dar tais pačiais metais grịžo ị aktyvią tarnybą, lankè D. Britanijos karališkojo jūrų laivyno koledžą, vyresniųjų karininkų kursus, nuo 1929 m. kovo buvo oro pajègų depo igulos narys. $1931 \mathrm{~m}$. vèl sušlubavus sveikatai, $1932 \mathrm{~m}$. pasitraukè iš tarnybos karo aviacijoje, gydèsi Šveicarijos kurorte Arozoje.

Lietuvos visuomenès ir politikų vertintas kaip populiariausias, vienas iš palankiausiai i lietuvių politinius siekius žiūrèjusių 1919-1920 m. laikotarpio D. Britanijos atstovų Lietuvoje. Apdovanotas Lietuvos didžiojo kunigaikščio Gedimino ordinu. Čia, matyt, reikšmès turejjo ir R. B. Wardo priklausymas katalikų konfesijai, kas buvo reta tarp britų elito atstovų. 
narių sąraše figūruoja jau $1919 \mathrm{~m}$. birželio 5 d. ${ }^{126}$, tačiau su misijos narių grupe ị Rygą atvyko tik liepos $25 \mathrm{~d} .{ }^{127} \mathrm{~S}$. Tallentsui liepos $30 \mathrm{~d}$. pradejus skirstyti užduotis misijos personalui, planuota, kad anksčiau D. Britanijos oro pajëgose tarnavęs plk. R. B. Wardas bus paskirtas organizuoti nuolatinio oro pašto ir lèktuvų, kuriais būtų skraidinami keleiviai, skrydžių tarp Baltijos šalyse veikusių britų karinių misijų ${ }^{128}$, mat jų nuo pat 1919 m. pavasario visiškai netenkino susisiekimo ir komunikacijų būklè Pabaltijyje. Pakeisti šią situaciją tuo metu buvo ir vienas pagrindinių H. Granto Watsono uždavinių. Jis tada skundèsi, jog Pabaltijyje paštas nereguliarus, užtrunka net iki dešimties dienų, susisiekimas geležinkeliais lètas, nepatikimas, traukiniai perpildyti; telefono ryšys neįmanomas dèl nepataisomų gedimų, o telegrafas, nors jo būklè ir geresnè, nepasiekia Anglijos ${ }^{129} .1919$ m. britų misijų ir jų padalinių Pabaltijyje, o kartu ir jų poreikis gerinti tiek tarpusavio, tiek su D. Britanija susisiekimą vis didèjo. Todèl liepos pabaigoje ir planuota, kad plk. R. B. Wardas spręs susisiekimo oro transportu maršrutais RygaLiepoja, Ryga-Talinas ir Ryga-Kaunas-Varšuva organizavimo klausimus.

Tačiau tuo metu dèl kelionių tarp Kauno ir Varšuvos nuolat kildavo problemų, o po 1919 m. rugpjūčio lenkų POW maišto Lietuvoje padètis tapo labai sudètinga. Ši aplinkybė, taip pat tai, kad sausumos keliais britams Kaunas buvo sunkiai pasiekiamas (Vakarų Lietuvoje vis dar stovèjo vokiečių pajègos) akivaizdžiai lèmé jų sprendimą Kaune ịkurti nuolatinį nedidelị misijos padalinị ir vadovauti jam skirti aviatorių, kuris prireikus galètų pasinaudoti oro keliu. Kartu su plk. R. B. Wardu rugpjūčio pabaigoje ị Kauną atvyko dar trys D. Britanijos atstovai: kpt. C. Dugganas (paskirtas atsakingu už transportą), E. J. Harrisonas (stenografas, atsakingasis sekretorius) ir klerkas S W. Powellas ${ }^{130}$. Šis S. Tallentso misijos padalinys pirmiausia èmè stebèti padètį vietoje ir kaupti britus dominančią informaciją. Surinktą informaciją

${ }^{126}$ Gruzdienė E. Užsienio valstybių karinès misijos pirmojoje Lietuvos Respublikoje 1919-1920 m., daktaro disertacija, p. 182.

127 Ten pat, p. 184.

128 Ten pat, p. 61.

129 Ten pat.

${ }^{130}$ Lietuvos centriniame valstybès archyve yra dokumentų apie R. B. Wardo misijos Kaune ịkūrimą: misijos narių ịgaliojimų pripažinimo dokumentai (lietuvių ir anglų kalbomis), leidimai vaikščioti po Kauną naktị (taip pat lietuvių ir anglų kalbomis). Žr.: LCVA, f. 383 , ap. 7 , b. $53,1.85-99$. 
R. B. Wardas privalèjo pateikti Rygoje reziduojančiam misijos vadovui, kuris gautus pranešimus patikrindavo, dažnai papildydavo ar pakomentuodavo ir tik tada išsiųsdavo ị $\mathrm{D}$. Britanijos užsienio reikalų ministeriją ar jos delegacijai Paryžiaus taikos konferencijoje ${ }^{131}$. Tik išimtiniu atveju (S. Tallentsui išvykus ar žinant jo išankstinę nuomonę) R. B. Wardas galèjo siųsti savo pranešimus tiesiogiai, be Tallentso vizos ar prierašo. Jau rugsèjo $3 \mathrm{~d}$. Wardas Tallentsui atsiuntė pirmąji savo pranešimą ir daugybę priedų. Šiame pranešime jis pateikè Lietuvos politinès situacijos apžvalgą, sugrupavęs medžiagą pagal temas: lietuvių ir lenkų santykiai, vokiečių ir kolčiakininkų okupacija tam tikrose Lietuvos vietose, bolševikai ${ }^{132}$. Šios ir kitos labai panašios buvo ir kitų kas savaitę R. B. Wardo Tallentsui siunčiamų pranešimų temos.

Laikraštis „Lietuva“ rugpjūčio 19 d. informavo, kad "gautomis žiniomis, netrukus $\mathfrak{i}$ Lietuvą turi atvykti Anglų karo komisija su pulkininku Robinsonu priešaky. Pulk. Robinsonas tuo tarpu eina Liepojaus komendanto pareigas ir ten kuria latvių pulką ${ }^{{ }^{133}}$. Atrodo, iš tiesų plk. H. Rowanas-Robinsonas (Rowan-Robinson Henry) ${ }^{134}$ netrukus pasirodè Lietuvoje, nes jau rugpjūčio $30 \mathrm{~d}$. tas pats laikraštis informavo,

${ }^{131}$ Gruzdienė E. Užsienio valstybių karinès misijos pirmojoje Lietuvos Respublikoje 1919-1920 m., daktaro disertacija, p. 62.

132 Ten pat.

${ }^{133}$ Politikos žinios. Santarve ir Lietuva // Lietuva, 1919, Nr. 180, p. 3.

${ }^{134}$ H. Rowanas-Robinsonas (Rowan-Robinson Henry) (1873-1947) - D. Britanijos karininkas, vèliau ištarnavęs iki generolo majoro laipsnio. Baigęs Kenterberio (Canterbury) karališkąją mokyklą, 1892 m. stojo ị artileristo tarnybą. 1901-1902 m. dalyvavo Būrų kare P. Afrikoje. Sparčiai kilo artilerijos karininko karjeros laiptais: 1911-1914 m. èjo Karališkosios karo akademijos artilerijos viršininko instruktoriaus pareigas. Toje pačioje akademijoje tarnavo ir 1915-1916 m. Vèliau dalyvavo Pirmojo pasaulinio karo veiksmuose, už tai buvo apdovanotas Belgijos ir Prancūzijos pasižymejjimo ženklais, tapo pirmos klasės generalinio štabo karininku. $1919 \mathrm{~m}$. buvo ịtrauktas ị formuojamą gen. H. Gougho misiją Pabaltijyje, 1919 m. birželio 23-liepos 11 d. ejo karinio gubernatoriaus Liepojoje pareigas. 1919 m. rudenị bendradarbiavo gen. H. A. Niesselio komisijos, kuri turèjo vokiečius galutinai iškraustyti iš Pabaltijo, veikloje. D. Britanijos karinei misijai Lietuvoje vadovavo iki $1920 \mathrm{~m}$. balandžio 17 d. Po to trumpam buvo komandiruotas ị Latviją, kur dalyvavo komisijos Latvijos ir Estijos sienai nustatyti darbe. 1921-1927 m. kaip D. Britanijos kariuomenès generalinio štabo karininkas tarnavo Indijoje. 1930-1934 m. - Irako armijos generolas inspektorius, dalyvavo karinèse operacijose Kurdistane. 1934-1944 m. - vadinamujų kadetų pajejgų (Army Cadet Force) Hampshire pulkininkas. 1940-1943 m. - gvardijos (Home Guard) bataliono vadas. Žinomas daugelio karinès, karinès istorinès tematikos publikacijų autorius. 


\section{LIETUVOS RESPUBLIKOS KARIUOMENĖ 1918-1940 M.}

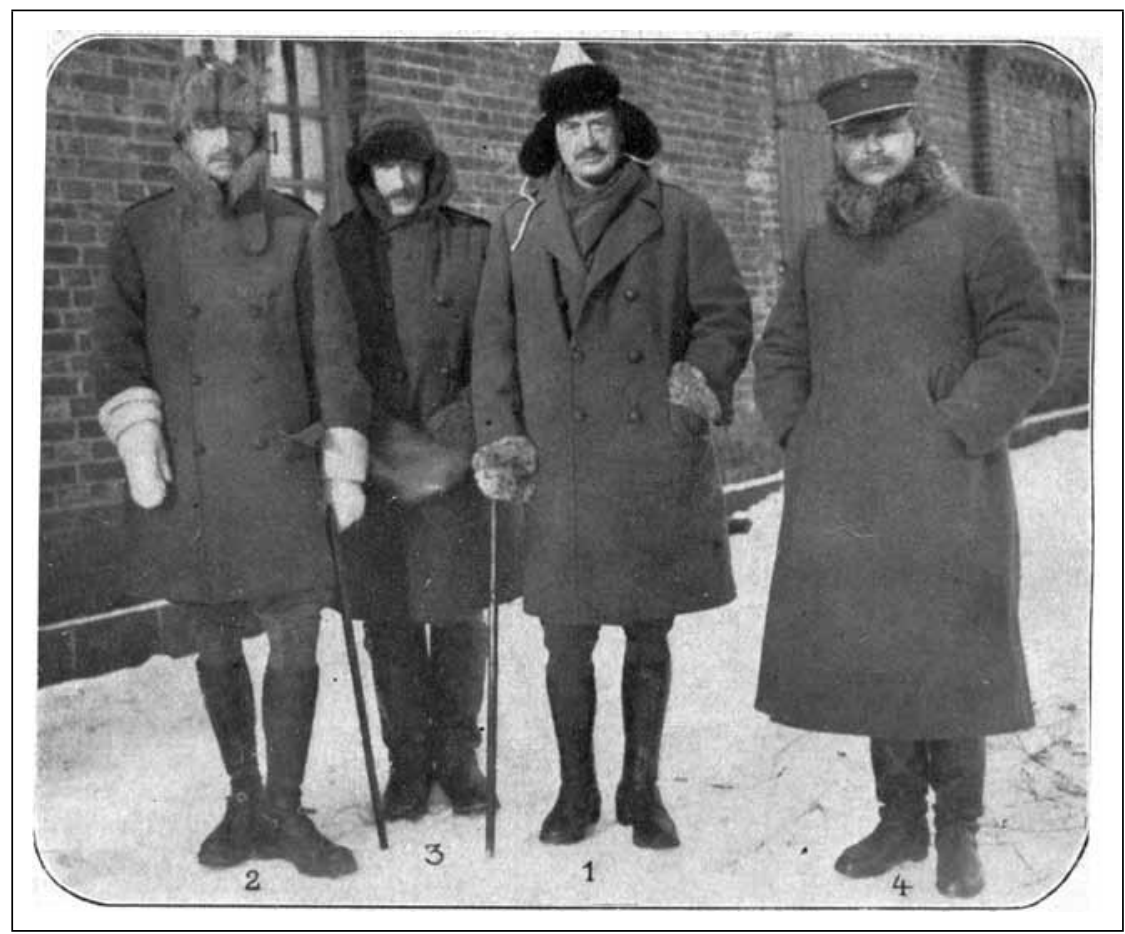

Alijantų misijos Pabaltijos valstybėse viršininkas 1. D. Britanijos gen. Turneris, 2. plk. Rowanas-Robinsonas, D. Britanijos karinės misijos Lietuvoje viršininkas, 3. mjr. Delahaye, gen. Turnerio asistentas, 4. mjr. A. Merkys, kariuomenès vado padejjejjas // Šešèliai, 1920, Nr. 2

kad „Robinsonas rugpjūčio 28 d. lèktuvu sugrịžo iš Rygos ir rugpjūčio 29 d. laikinai išvyko ị Varšuvą “135. Plk. H. Rowanas-Robinsonas turèjo vadovauti gen. H. Gougho karinès misijos skyriui Kaune. Buvo numatyta, kad tą skyrių sudarys pirmos klasès generalinio štabo karininkas (vadovas), štabo kapitonas, karininkas šifruotojas, karininkas vertėjas, klerkas, du pasiuntiniai ir vairuotojas, taigi iš viso 8 asmenys ${ }^{136}$. Gen. H. Gougho

${ }^{135}$ Kauno kronika // Lietuva, 1919, Nr. 190, p. 3.

${ }^{136}$ Gen. H. Gougho karinès misijos struktūros schemą žr.: War Office, Memorandum on Lieutenant-General Sir Hubert Goug's Mission in the Baltic States, 20 August 1919, CAB 24/87. Interneto prieiga http://www.nationalarchives.gov.uk/documentsonline/details-result.asp?querytype $=1 \&$ resultcount $=1 \& E d o c \_I d=8050486$ 1. 91-92. Beje, majoras A. H. Keenanas irgi buvo įtrauktas ị formuojamą H. Gougho misiją, paskirtas generalinio 
misija dar turejjo struktūrinių padalinių - pagal planą numatytų skyrių Helsinkyje, Taline ir Rygoje. Skyrių vadovai atsiskaitydavo pagrindiniam misijos štabui Helsinkyje. Tačiau specialiu D. Britanijos karo ministerijos nurodymu, esant ypatingai situacijai, jie turèjo tiesiogiai informuoti Karo ministeriją ir tik po to pagrindinị misijos štabą Helsinkyje ${ }^{137}$.

Planuotą gen. H. Gougho misijos darbą 1919 m. rugpjūtị komplikavo tam tikra jos „viršūnès“ krizé, neabejotinai atsiliepusi ir skyriaus Kaune veiklai, pirmiausia dèl pakitusių iš pradžių numatytų subordinacijos ryšių. Matyt, gen. H. Goughas pernelyg pasidavė Karo ministerijos, kuri buvo už aktyvią intervenciją i Rusiją ir kuo greitesnị Petrogrado užèmimą, ittakai. Ministerija nebuvo linkusi analizuoti užsienio politikos plonybių ir suteikè H. Goughui plačią veikimo laisvę. Prireikus skubios Estijos karinès paramos, gen. H. Goughas rugpjūčio $10 \mathrm{~d}$. savo iniciatyva nurodè suformuoti vadinamąją Šiaurès vakarų Rusijos vyriausybę (vadovaujamą S. Liasonovo) Taline, kuri nedelsiant pripažintų Estijos nepriklausomybę, kas rugpjūčio $14 \mathrm{~d}$. ir buvo padaryta ${ }^{138}$. Tačiau tai sukèlè visos Rusijos „baltųjų“ stovyklos pasipiktinimą. Pasipylè skundai Antantės atstovams. Gresiant skandalui D. Britanijos užsienio reikalų ministerija buvo priversta reaguoti ir imtis dèl H. Gougho atitinkamų priemonių. G. Curzonas ir A. Balfouras griežtai kritikavo nesuderintus generolo veiksmus ${ }^{139}$. Rugpjūčio 19-20 d. surengtose diskusijose D. Britanijos ministrų kabinetas taip pat kritikavo gen. H. Gougho veiksmus ir tučtuojau atšauke ji Londoną ${ }^{140}$. Vien Karo ministerija ji palaikè, tačiau ir ji galejo tik pareikš-

štabo 2-ojo laipsnio karininku gen. H. Gougho štabe Helsinkyje.

${ }^{137}$ Gruzdienè E. Užsienio valstybių karinès misijos pirmojoje Lietuvos Respublikoje 1919-1920 m., daktaro disertacija, p. 157-158.

${ }^{138}$ Hovi O. The Baltic Area in British Policy, p. 168.

139 Ten pat.

${ }^{140}$ Ten pat. E. Gruzdiené, remdamasi D. Britanijos archyviniais dokumentais, teigia, jog 1919 m. birželio 23 d. gen. H. Goughas lankèsi ir Kaune (Gruzdienè E. Užsienio valstybių karinès misijos pirmojoje Lietuvos Respublikoje 1919-1920 m., daktaro disertacija, p. 161), bet jokiuose lietuviškuose šaltiniuose apie tai neužsimenama. Tačiau žinoma apie asmenini H. Gougho indèli svarstant Lietuvos reikalus Paryžiuje. Pvz., 1919 m. liepos pradžioje jis kalbèjo Baltijos komisijos posėdyje: teigè, kad Lietuva turi pakankamai finansinių ištekliụ savo valstybei ir kariuomenei išlaikyti (Čepènas P. Naujųjų laikų Lietuvos istorija, p. 535). Tačiau net $1919 \mathrm{~m}$. rugpjūtị atšaukto H. Gougho ịtaka sprendžiant Lietuvos klausimą buvo juntama: rugsèjo viduryje Antantès Aukščiausiojoje Taryboje 
ti nepasitenkinimą dèl vyriausybès pozicijos. Vadovavimą misijai perèmè Helsinkio misijos vadovas gen. Frederikas G. Marshas, bandęs tęsti H. Gougho igyvendinamą politiką ${ }^{141}$. Jis rugpjūčio 26 d. Rygoje organizavo visų antisovietinių jègų konferenciją. Joje dalyvavo Estijos, Latvijos, Lenkijos, „baltujų“ rusų, taip pat Lietuvos atstovai ${ }^{142}$. Šioje konferencijoje buvo nutarta rugsèjo $15 \mathrm{~d}$. pradèti koordinuotą bolševikų pajègų puolimą. Tačiau puolimas neįvyko, nes jau konferencijos eiga rode, kad jos dalyvius daugiau veiksnių skyrė nei vienijo, pvz., plk. P. Bermontas vos nesusimušè su Lietuvos atstovu plk. Beniaševičiumi ${ }^{143}$. Tačiau reikšmingiausias dalykas, dèl kurio karingumas išgaravo, buvo ne tarp antibolševikinių jègų atsiradusi trintis, ne D. Britanijos užsienio reikalų ir karo ministerijų nesutarimai, o $1919 \mathrm{~m}$. vasaros pabaigoje besikeičianti britų valstybès politika sovietų atžvilgiu. Intervencija Rusijoje tapo sunkia našta biudžetui, todèl ne tik šios šalies socialistai, liberalai, bet ir dalis konservatorių ėmè daryti spaudimą vyriausybei, kad ši nutrauktų karinę paramą baltụjų armijoms, sudarytų taiką su bolševikų vyriausybe ir pabandytų išnaudoti ekonominius Rusijos rinkos privalumus ${ }^{144}$. Generolo F. G. Marsho ir visos misijos veikla natūraliai atsidūrè politinių pacifistinių tendencijų ir aktualijų šešèlyje. Apskritai D. Britanijos vyriausybę tuo metu rytiniame Pabaltijyje èmè labiau dominti ne antibolševikinis, o rusų ir vokiečių suartėjimo aspektas. Kadangi iš esmès tai buvo aktualiausia Latvijos teritorijoje, padidèjo karinès misijos skyriaus Rygoje, vadovaujamo gen. A. Burto, reikšmè. Visų minètų ịvykių ir tendencijų fone karinès misijos skyriaus Kaune, vadovaujamo plk. H. Rowano-Robinsono, įkūrimas ir pirmieji žingsniai tarsi liko nepastebèti.

Paryžiuje jis perskaitė pranešimą apie Baltijos šalių padèti. Lietuvos delegacijos vicepirmininkas Tomas Naruševičius tada susitiko su juo ir sužinojo, kad Antantè svarstė galimybę leisti J. Pilsudskiui okupuoti Lietuvą ir sulaikyti ị regioną besiveržiančius bermontininkus (Gaigalaitè A. Lietuva Paryžiuje 1919 metais, p. 58-59).

${ }^{141}$ Hovi O. The Baltic Area in British Policy, p. 168.

${ }^{142}$ Anderson E. Die Baltische Frage und die internationale Politik, S. 366; Gaigalaitè A. Lietuva Paryžiuje 1919 metais, p. 60, 128. Apskritai ši konferencija yra plačiai žinoma tiek Lietuvos, tiek kitų šalių istoriografijoje.

${ }^{143}$ Laurinavičius Č. Lietuvos-Sovietų Rusijos taikos sutartis, p. 20-21.

${ }^{144}$ Naujas tendencijas D. Britanijos visuomeneje ir politikoje pastebejo ir Lietuvos atstovas Londone V. Čepinskis ir tai išdèstè savo pranešime vyriausybei (V. Čepinskio 19190814 pranešimas ministrų kabinetui. LCVA, f. 923, ap. 1, b. 57, 1. 69). 
Gen. H. Gougho misijos „viršūnių“ krizè tiesiogiai palietė ir plk. S. Tallentso vadovaujamą pasiuntinybę ir turejjo ịtakos jos veiklai. Tuo metu, kai buvo formuojama minètoji Šiaurès vakarų Rusijos vyriausybė, S. Tallentsas kaip tik buvo išvykęs iš Pabaltijo ir visus reikalus tvarkyti palikęs rezidavusiam Taline savo pavaduotojui plk. ltn. H. Pirie-Gordonui. Šis vietoje plk. S. Tallentso turèjo patarinèti gen. H. Gougho misijai politiniais klausimais, todèl kaip tik jam teko nemaža atsakomybès dalis dèl Šiaurès vakarų Rusijos vyriausybès sudarymo inicijavimo (nors, atrodo, pagrindinis iniciatorius visgi buvo pats gen. H. Goughas). Todèl, kilus minètam diplomatiniam sambrūzdžiui, ị D. Britaniją, be gen. H. Gougho, buvo atšauktas ir plk. ltn. H. Pirie-Gordonas ${ }^{145}$. Plk. S. Tallentsui teko aiškintis dèl savo pavaduotojo veiksmų, restruktūrizuoti misijos darbą ir tai, be abejo, viena iš priežasčių, kodèl neįvyko jo rugpjūčio $20 \mathrm{~d}$. planuotas vizitas ị Lietuvą. Be to, tomis dienomis kaip tik išryškejjo ir plk. S. Tallentso misijos vidaus nesutarimai - tarp jo ir patarejo finansiniams ir ekonominiams reikalams W. Macduffo, dèl to pastarasis buvo atleistas iš pareigų ir išsiųstas atgal ị $\mathrm{D}$. Britaniją ${ }^{146}$. Atsiradus tokių nesklandumų, Londone natūraliai kilo abejonių dèl plk. S. Tallentso misijos personalo tinkamumo ir patikimumo. Itarinejjama D. Britanijos užsienio reikalų ministerija išsigynė pareiškusi, kad „neturèjo progos įtakoti plk. S. Tallentso misijos narių pasirinkimo, kadangi jis pats èmési komplektuoti savo misiją “ ${ }^{147}$. Plk. S. Tallentsas èmèsi vadovauti misijai, bet nedirbo Užsienio reikalų ministerijoje (Foreign Office), tik 1919 m. liepos 30 d. buvo patvirtinta, kad misija pavaldi šiai ministerijai ${ }^{148}$. Sudarant misiją Karo ministerija (War Office) taip pat neprisièmè finansinès atsakomybès teigdama, jog „misija tiesiogiai nevykdys karinès paskirties uždavinių ir visa atsakomybė už šios misijos veiklą atiteko D. Britanijos užsienio reikalų ministerijai“"149. Nesant nesklandumų, šie tam tikra britiška specifika pasižymintys organizaciniai dalykai būtų likę nepastebėti, tačiau šįart

\footnotetext{
${ }^{145}$ Hovi O. The Baltic Area in British Policy, p. 168.

${ }^{146}$ Gruzdienė E. Užsienio valstybių karinès misijos pirmojoje Lietuvos Respublikoje 1919-1920 m., daktaro disertacija, p. 57.

147 Ten pat, p. 55.

148 Ten pat, p. 54.

149 Ten pat, p. 55.
} 
jie iškilo gana aštriai. Be to, $D$. Britanijos užsienio reikalų ministerijoje atsirado gen. H. Gougho misijos narių skundų dèl plk. S. Tallentso vadovavimo stiliaus, tačiau šiuo požiūriu ministerija palaike plk. S. Tallentsą. Taigi pastarajam $1919 \mathrm{~m}$. rugpjūčio gale rūpesčiu tikrai netrūko.

Tuo metu Lietuvos vyriausybè stengèsi toliau plètoti rugpjūčio $15 \mathrm{~d}$. ministrų kabineto posèdyje aprobuotą politiką D. Britanijos atžvilgiu. Rugpjūčio $24 \mathrm{~d}$. posèdyje vèl buvo tęsiamas koncesinių pasiūlymų britams aptarimas. Ministras J. Šimkus pasitarimo dalyvius informavo, kad reikalui aptarti plk. S. Tallentsas „dabar" atvyksta ị Lietuvą ${ }^{150}$. Kaip žinome, tomis dienomis $\mathfrak{i}$ Kauną atvyko ne pats misijos vadovas, o plk. R. B. Wardo vadovaujama misijos grupé, tačiau iš J. Šimkaus kalbos galima spręsti, kad lietuviai plk. S. Tallentsą tebelaikè svarbiausiu derybų partneriu.

Dar 1919 m. sausį Lietuvos vyriausybei svarstant valstybingumo perspektyvas, kaip jau minèta, figūravo ir lokalios Baltijos šalių sajungos, galbūt globojamos D. Britanijos, vizija. Ši idèja nebuvo pamiršta ir vèliau, o kai rugpjūčio 15 d. Jonas Šliūpas, bene žinomiausias lietuvių ir latvių politinio suartèjimo šalininkas, buvo paskirtas atstovu Rygoje, ji tarsi gavo naują impulsą ${ }^{151}$. Dar svarbesnis impulsas rytinès Baltijos šalių pakrantès šalių vienybei atkurti tuo metu buvo regioninès politikos aktualijos: sovietinei Rusijai tapo paranku su šiomis šalimis sudaryti taiką, ir ji èmé teikti tokius pasiūlymus ${ }^{152}$. Estijai pirmajai gavus tokị pasiūlymą, Lietuva rugsėjo $10 \mathrm{~d}$. Rygoje inicijavo neoficialų trijų šalių atstovų pasitarimą dèl bendro Baltijos fronto sudarymo santykiams su bolševikų valstybe nustatyti ${ }^{153}$. Rusija, be kita ko, tuoj pat izžvelgè $\mathrm{D}$. Britanijos kèslus taikos sudarymo klausimu užbeggti už akių. Rygos konferencija svarste valstybių susivienijimo galimybę, tačiau nutare geriau periodiškai šaukti delegacijų pasitarimus, nei bandyti sudaryti vieną politinę instituciją. Rusija šiame kontekste vienareikšmiškai jž̌velgè D. Britanijos interesus, kad Baltijos valstybių sąjunga būtų sukurta ${ }^{154}$. Tuo metu, daugiausia lietuvių iniciatyva, rugsejo $14 \mathrm{~d}$. Taline buvo surengtas antrasis pasitarimas, jame

15019190824 Lietuvos vyriausybès posèdžio protokolas. LCVA, f. 923, ap. 1, b. 57, 1. $92-92$ a. p.

${ }^{151}$ Senn A. E. Lietuvos valstybès atkūrimas 1918-1920, Vilnius, 1992, p. 105.

${ }^{152}$ Plačiau žr.: Laurinavičius Č. Lietuvos-Sovietų Rusijos taikos sutartis, p. 14-26.

${ }^{153}$ Senn A. E. Lietuvos valstybès atkūrimas 1918-1920, p. 115-116.

154 Ten pat. 
dalyvavo ir Suomija ${ }^{155}$. Estams pasiūlius, ị ši pasitarimą buvo pakviesti ir D. Britanijos stebètojai, pirmiausia plk. S. Tallentsas. Kaip teigiama, konferencijos delegatai beveik nuolat konsultuodavosi su Antantės atstovais ${ }^{156}$. Buvo nutarta sudaryti bendrą šalių bloką deryboms su bolševikais vesti. Lietuvai pasitarimuose atstovavo J. Šimkus ir premjeras M. Sleževičius. Netrukus jie pakvietė plk. S. Tallentsą ì Lietuvą. Rugsèjo $17 \mathrm{~d}$. Lietuvos vyriausybės posėdyje Petras Leonas informavo, kad plk. Tallentsas „rytoj išvažiuoja iš Rygos ị Kauną ir prašo parūpinti jam butą “157.

Tai buvo pirmasis, tiesa, labiau pažintinis, plk. S. Tallentso vizitas Lietuvoje. Jo metu pulkininkas lankèsi ir Lietuvos prezidento A. Smetonos namuose $\mathrm{e}^{158}$.

Viena iš šio laikotarpio plk. S. Tallentso pokalbių su Lietuvos atstovais temų buvo ir Lietuvos ministrų kabineto krizè. Mat ši M. Sleževičiaus vyriausybẻ buvo koalicinè, premjero bendražygiai radikalai joje turèjo tik nežymią persvarą, o kitus postus buvo užėmę aiškūs dešinieji, kurie dare įtaką Prezidento institucijai, Valstybès Tarybai ir kariuomenei ${ }^{159}$. Kai 1919 m. vasaros pabaigoje dèl finansinès krizès prireikè mažinti ministerijų skaičių, trintis tarp radikalų ir konservatorių labai padidejjo. Mat, sumažejus ministerijų, būtų tekę trauktis ir atitinkamiems ministrams. Tačiau nei radikalai, nei konservatoriai nenorejo silpninti pozicijų ${ }^{160}$. Šios politinès kovos kontekste rugpjūčio pabaigoje iš Paryžiaus ị Kauną grịžo ir prof. A. Voldemaras, Taikos konferencijos delegacijos pirmininkas, vienas iš dešiniųjų lyderių, ir tai akivaizdžiai turèjo ịtakos vyriausybès užsienio politikai, taip pat ir pasitarimams su britais: pvz., rugpjūčio paskutinèmis dienomis prireikus ị Rygą derètis su britais dèl ekonomikos

\footnotetext{
155 Ten pat, p. 116; Laurinavičius Č. Lietuvos-Sovietų Rusijos taikos sutartis, p. 38-39.

${ }^{156}$ Senn A. E. Lietuvos valstybės atkūrimas 1918-1920, p. 116. A. Gaigalaitė mini, jog jau Rygos konferencijos metu rugsèjo $10 \mathrm{~d}$. S. Tallentsas ten surengè susitikimą, ị kurị buvo pakviesti ir atvyko visų trijų šalių generalinių štabų viršininkai ir karo vadai. Svarbiausias svarstomas klausimas - Pabaltijo valstybių sąjungos sudarymas, karinis, politinis ir ekonominis bendradarbiavimas (Gaigalaitè A., Lietuva Paryžiuje 1919 metais, p. 129).

15719190917 Lietuvos vyriausybès posèdžio protokolas. LCVA, f. 923, ap. 1, b. 57, 1. 119. ${ }^{158}$ Gruzdienė E. Užsienio valstybių karinès misijos pirmojoje Lietuvos Respublikoje 1919-1920 m., daktaro disertacija, p. 60.

${ }^{159}$ Laurinavičius Č. Lietuvos-Sovietų Rusijos taikos sutartis, p. 27.

160 Ten pat, p. 28.
} 
reikalų vèl pasiųsti J. Šimkų, A. Voldemaro iniciatyva kartu su juo buvo pasiųstas iš Paryžiaus grịžęs A. Voldemaro bendražygis Martynas Yčas ${ }^{161}$. Vos tik atvykusi ị Kauną plk. R. B. Wardo misija taip pat buvo supažindinta su vidaus politikos batalijomis, matyt, kartu stengiantis formuoti ir atitinkamas jos nuostatas. Jau rugsejjo pradžioje plk. R. B. Wardas pasiūlè vyriausybei „rekonstruoti iš vidaus kabinetą ir sumažinti ministrų skaičių ligi 6, kadangi egzistuojantis kabinetas yra per didelis tokiai šaliai, sunkiai valdomas ir griozdiškas" ${ }^{162}$.

Tačiau svarbiausia šio laikotarpio politikos aktualija vis dèlto buvo taikos su bolševikais klausimas, nors juo taip pat siekta pasinaudoti vidaus politineje kovoje. Lietuvos padètis $1919 \mathrm{~m}$. vasaros pabaigoje buvo tokia, kad būtinai reikejo keisti politiką. Nors bolševikų kariuomenè jau buvo išvyta iš etnografinès teritorijos, Antantès nurodymu pagrindinès Lietuvos karinès pajègos ir toliau prieš ją buvo telkiamos, o tuo metu augantis lenkų ir kolčiakininkų agresyvumas kèlè kur kas didesni pavojų. Atrodè, kad toliau vykdant Antantès nurodymus netrukus bus prieita aklaviete் $\dot{e}^{163}$ : Paryžiaus taikos konferencija jau ejjo ì pabaigą, o Lietuva žadèto Antantès palaikymo nesulaukè. Tenykščiai sprendimai rodo, jog po kai kurių dvejonių Antantė pasirinko vieningos Rusijos atkūrimo idejją, o naujai besikuriančioms valstybėms, tarp jų ir Lietuvai, buvo primestas Rusijos skaldytojų vaidmuo. Oficialus kelias ị valstybingumą buvo atkirstas, tačiau galbūt buvo galima pasinaudoti kokiais nors aplinkkeliais. Lietuvos vidaus politikoje visų pirma tai reiškè konservatorių, kurie besąlygiškai orientavosi ị Antantę, politinès linijos susilpnejjimą. Dèl susiklosčiusios situacijos reikejjo imtis savarankiškesnès aktyvios politikos, ir tam geriau tiko radikalai, apeliuojantys ị plačiųjų Lietuvos gyventojų sluoksnių pritarimą ir paramą. Sovietų Rusijos pasiūlymai atvėrẻ ne tik konkretų paliaubų (eventualios taikos) kelią. Alternatyvi galimybẻ reiškẻ santykių su Antante aktyvinimą, taikos derybų klausimą panaudojant kaip tam tikro spaudimo jai priemonę: tikètasi, jog plyšio antisovietiniame fronte atsiradimo grèsmė privers Antantę skirti Baltijos valstybėms daugiau

${ }^{161} 19190828$ Lietuvos vyriausybės posėdžio protokolas. LCVA, f. 923, ap. 1, b. 57, 1. 97 a. p. ${ }^{162}$ Gruzdienė E. Užsienio valstybių karinès misijos pirmojoje Lietuvos Respublikoje 1919-1920 m., daktaro disertacija, p. 75-76.

${ }^{163}$ Laurinavičius Č. Lietuvos-Sovietų Rusijos taikos sutartis, p. 30. 
palankaus dèmesio, suteikti joms didesnę politinę, ekonominę ir karinę pagalbą ${ }^{164}$. Minètų Rygos ir Talino konferencijų organizavimas ir reiškè politikos aktyvinimą. Konservatoriai būgštavo, jog pradejjus taikos derybas su bolševikais Antante galètų leisti lenkams užimti visą Lietuvąą ${ }^{165}$. Tačiau rugsėjo 18-19 d. kabineto posèdžiuose M. Sleževičiaus radikalai sugebejo įveikti konservatorių, pirmiausia A. Voldemaro, pasipriešinimą ir legalizuoti derybų su sovietais klausimą ${ }^{166}$. Tai, jog radikalai ryžtingai gynė savo poziciją ir laimèjo tuo metu, kai Kaune viešèjo plk. S. Tallentsas, rodo, jog pastarasis ir jo vadovaujama misija bent jau nesipriešino M. Sleževičiaus pasirinktam kursui.

M. Sleževičius aiškiai stojo už taikos su bolševikais sudarymą argumentuodamas tuo, jog daugiau kariaudami „valysime kelią Judeničiui, Kolčiakui ir Denikinui - didžiausiems mūsų priešams, kurie pirmiausia pasistengtų panaikinti mūsų nepriklausomybę ${ }^{\text {"167 }_{16}}$. Tačiau premjero bendraminčiai tiek karo, tiek taikos su bolševikais klausimą manė glaudžiai susieti su britų laikysena: dar rugpjūčio $17 \mathrm{~d}$. buvo priimtas atsargus nutarimas, kuriame pabréžiama, jog „mūsų užsienio politika turi krypti tų Anglijos srovių pusèn, kurios siekia taikos su bolševikais. Bet toji orientacija turi būti labai atsargiai vedama, kad nepakenktų, jeigu laimès militaristai “168. Rugsejjo viduryje premjeras, atrodo, jau buvo ịsitikinęs, kad taikingos britų tendencijos ịsivyraus. Jis samprotavo, jog „jeigu paimtų viršų Askvito grupè, anglai pradètų derybas su bolševikais, ir jeigu mes būtume susitarę su bolševikais, anglai atsistotų prieš įvykusį faktą ir priversti būtų pripažinti mūsų nepriklausomybę "169. Tuo metu atrodè, kad M. Sleževičiaus šalininkai pasiekè aiškią pergalę pagrindiniuose politinių batalijų frontuose: jų užsienio politikos aktyvioji linija buvo ịtvirtinta, o rugsejjo $25 \mathrm{~d}$. iš vyriausybès pasitraukè ministrai tautininkai - atsirado galimybè reorganizuoti vyriausybę pasitenkinant mažesniu ministrų

\footnotetext{
164 Ten pat, p. 35.

16519190919 Lietuvos vyriausybės posèdžio protokolas. LCVA, f. 923, ap. 1, b. 57, 1. 126127.

${ }^{166}$ Laurinavičius Č. Lietuvos-Sovietų Rusijos taikos sutartis, p.39-40.

16719190919 Lietuvos vyriausybès posėdžio protokolas. LCVA, f. 923, ap. 1, b. 57, 1. 126.

16819190817 Lietuvos vyriausybès posėdžio protokolas. Ten pat, 1. 79.

16919190919 Lietuvos vyriausybès posedžio protokolas. Ten pat, 1. 126-127.
} 
skaičiumi, t. y. nebepriimant konservatorių ${ }^{170}$.

Tačiau rugsèjo $26 \mathrm{~d}$. pas M. Sleževičių atvyko plk. R. B. Wardas ir ėmé priekaištauti ne tik dèl tautininkų atsistatydinimo, bet ir dèl eventualios taikos su sovietais. Galų gale jis pagrasino, kad jeigu taikos nebus atsisakyta, D. Britanija neberems Lietuvos vyriausybès, konkrečiai - nebeduos tuo metu labai reikalingų kreditų "171. Britų atstovo pareiškimas rodé, jog susvyravo esminė M. Sleževičiaus šalininkų atrama ir jie jau buvo linkę atsisakyti savo pozicijos - taikos derybų su Rusija.

Tuo metu Tartu mieste buvo surengta nauja Baltijos valstybių konferencija - anksčiau numatytas Talino konferencijos tęsinys. I ją Lietuvos atstovai vyko be entuziazmo - D. Britanijos poziciją, niekais pavertusią anksčiau puoselètas viltis ${ }^{172}$, išsake plk. R. B. Wardas. Tačiau lietuvių atstovai Rygoje iš J. Šliūpo sužinojo, kad britai vis dèlto nesipriešina Baltijos valstybių taikos deryboms su Rusija. J. Šliūpas tvirtino gavęs atitinkamą plk. S. Tallentso raštą ir pasiuntęs jị i Kauną. Lietuviai asmeniškai kreipèsi ị plk. S. Tallentsą, ir šis patvirtino, kad Baltijos valstybių atstovams įteikė slaptą raštą, pridurdamas, jog tik jame išdèstyta oficiali D. Britanijos pozicija, nors egzistuojanti ir neoficiali, priešinga, nuomoné ${ }^{173}$. Plk. S. Tallentso rašte buvo rašoma, jog D. Britanijos vyriausybé mananti, kad ji neturi teisès daryti spaudimo Baltijos valstybėms dèl ju iniciatyvos, jos pačios privalo spręsti, „koks veikimas geriausiai tarnaus jų tautiškam būviui apsaugoti“, ar sudaryti su Sovietų Rusijos vyriausybe sutartis ${ }^{174}$. Tai sužinoję Lietuvos delegatai Tartu konferencijoje vèl buvo pasirengę pradèti minètas taikos derybas ${ }^{175}$, tačiau grịžę ị Kauną sužinojo, kad M. Sleževičiaus kabinetas atsistatydino. Minèta plk. R. B. Wardo pozicija nedviprasmiškai lèmé tokią baigtị. İdomiausia, jog kaip tik tuo metu D. Britanija pripažino Lietuvą de facto.

Naujųjų Baltijos valstybių pripažinimas apskritai tuo metu Antantės

${ }^{170}$ Laurinavičius Č. Lietuvos-Sovietų Rusijos taikos sutartis, p. 43-44.

${ }^{171} 19190926$ Lietuvos vyriausybès posėdžio protokolas. LCVA, f. 923, ap. 1, b. 57, 1. 136.

${ }^{172}$ Laurinavičius Č. Lietuvos-Sovietų Rusijos taikos sutartis, p. 44-45.

${ }^{173}$ Lietuvos delegacijos Tartu konferencijoje (1919 09 29-10 05) ataskaita vyriausybei. LCVA, f. 383, ap. 7, b. 55, 1. 117.

${ }^{174}$ D. Britanijos notos Baltijos valstybèms vertimas ị lietuvių k. Ten pat, 1. 132.

${ }^{175}$ Lietuvos delegacijos Tartu konferencijoje (1919 09 29-10 05) ataskaita vyriausybei. Ten pat, 1. 120. 
šalims buvo gana komplikuotas dalykas. Estiją ir Latviją D. Britanija pripažino de facto jau 1918 m. pabaigoje. Lietuva tokio pripažinimo nesulaukè greičiausiai dèl Vakaruose sunkiai perprantamų Lietuvos ir Lenkijos santykių ir jų perspektyvų. Bet 1919 m. ìvykių raida liudija, jog ir pripažinimas estams ir latviams buvo menka paguoda. Tai aiškiai rodo Baltijos šalių problematikos svarstymas Paryžiaus taikos konferencijoje. Vakarų šalys rytinę Baltijos pakrantę tebelaikė integralia Rusijos dalimi ir užmegzdamos santykius akivaizdžiai prioritetą teikè „baltųjų“ rusų politikos atstovams. I judejjimus dèl nepriklausomybès dèmesio buvo kreipiama tik tiek, kiek jie galejo pasitarnauti kovoje su bolševizmu. Pvz., liepos 28 d. Latvijos diplomatas Paryžiuje Janis Seskis savo draugų britų ir amerikiečių buvo informuotas, jog Baltijos šalys negali tikètis nepriklausomybès pripažinimo ${ }^{176}$. Estijos delegatas Jaanas Poska dèl to taip pat prarado visas viltis ir kaip tam tikrą išeiti pasiūlè, sudarius bendrą Suomijos, Estijos, Latvijos ir Lenkijos diplomatinị frontą, pasirašyti taiką su Sovietų Rusija ${ }^{177}$. Rugpjūtị estams jau atvirai šnekant apie taikos su bolševikais galimybę, jei Antantẻ neatsižvelgs ị jų lūkesčius, rugpjūčio 20 d. Antantès Aukščiausioji taryba vis tiek pareiškè, kad pabaltijiečių pretenzijos nesuderinamos su paramos Kolčakui ir Denikinui politi$\mathrm{ka}^{178}$. Kaip paprastai, pabaltijiečių reikalų svarstymą Antantès institucijose inicijuodavo britai, tikèdamiesi kaip nors rasti suinteresuotas puses tenkinantị sprendimą. Liepą G. Curzonas vis dar vylèsi, kad „pakraščių“ vyriausybès ir Rusų politinès tarybos atstovai Paryžiuje susitars dèl federacijos, tačiau kiti D. Britanijos užsienio reikalų specialistai, pvz., A. Balfouras, suprato, jog tarp siekių žiojejjanti praraja yra per plati ${ }^{179}$. Rugpjūtị ir G. Curzonas jau pritarè Lietuvos pripažinimui de facto, kad būtų „sure-

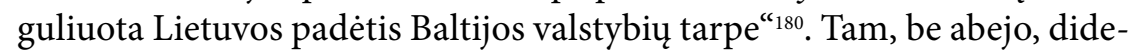
lę ịtaką turèjo tai, kad britų misijų nariai èmè tiesiogiai reziduoti Lietuvos teritorijoje ir apie padètị vietoje siųsti išsamius pranešimus, kurie aiškiai

\footnotetext{
${ }^{176}$ Anderson E. Die Baltische Frage und die internationale Politik, S. 363.

177 Ten pat. Lietuvos delegacija Paryžiaus taikos konferencijoje, daugiausia A. Voldemaro „dèka“, laikèsi šiek tiek nuošaliai nuo kitų pabaltijiečių ir kurị laiką netgi buvo labiau linkusi bendradarbiauti su „baltųjų“ rusų atstovais.

${ }^{178}$ Anderson E. Die Baltische Frage und die internationale Politik, S. 365.

${ }^{179}$ Senn A. E. Lietuvos valstybès atkūrimas 1918-1920, p. 107-108.

180 Ten pat, p. 108; Hovi O. The Baltic Area in British Policy, p. 177.
} 
rodė nepriklausomybės idejos gyvybingumą ir atsparumą pašalinių jègų spaudimui. Rugpjūčio viduryje lietuvių šaltiniai iš Londono pranešè, kad Lietuvos atstovui V. Čepinskiui jau pažadètas D. Britanijos pripažinimas $^{181}$. Britų diplomatijos tendencijos, bent jau savo raiška, šiuo klausimu ir liko nevienareikšmès, ką, kaip jau minèta, lietuviams tiesiai pasakè ir S. Tallentsas. Dar rugsejjo 16 d. G. Curzonas D. Britanijos misijoms nurodè perspèti Pabaltijo šalių vyriausybes, kad nesiderètų su Sovietų Rusija dèl taikos. Tai tiesiogiai buvo siejama ir su nepriklausomybès pripažini$\mathrm{mu}^{182}$. Tačiau jau rugsèjo $23 \mathrm{~d}$. G. Curzonas pranešè plk. S. Tallentsui, kad D. Britanijos vyriausybè pripažins Lietuvą de facto tokiomis pat sąlygomis kaip Estiją ir Latviją, ir paprašè šią žinią perduoti ị Kauną ${ }^{183}$. Rugsèjo 25 d. G. Curzonas atsiuntė telegramą-aplinkraštị, kuriame oficialiai aiškinama D. Britanijos politika Baltijos kraštų atžvilgiu: pirmiausia tai, kad pripažinimas de facto garantuojamas visoms trims šalims ${ }^{184}$, tačiau kartu ir tai, kad D. Britanija negali toliau remti Baltijos valstybių ekonomiškai, daugiau suteikti paskolų ir kreditų, todèl neturi teisès ir reikalauti, kad šios valstybès imtųsi kokių nors ypatingų veiksmų. Kitaip tariant, britai vengè konkrečios atsakomybės ${ }^{185}$. Kai rugsèjo $20 \mathrm{~d}$. Karo ministerijos vadovas W. Churchillis pasiūlè premjerui D. Lloydui George’ui pripažinti Baltijos šalių nepriklausomybę, gavo neigiamą atsakymą ${ }^{186}$. Tokio elgesio galèjo būti ne vienas paaiškinimas. Pirmiausia tai, kad W. Churchillis jaute palankumą šioms šalims ir jas vertino pirmiausia dèl jų aktyvumo kovoje su bolševizmu, o premjeras jau buvo linkęs pereiti prie taikių santykių. Taip pat po minèto atvejo, kai kilo diplomatinis nepasitenkinimas

\footnotetext{
${ }^{181}$ Senn A. E. Lietuvos valstybės atkūrimas 1918-1920, p. 108.

${ }^{182}$ Anderson E. Die Baltische Frage und die internationale Politik, S. 366.

${ }^{183}$ Senn A. E. Lietuvos valstybès atkūrimas 1918-1920, p. 123.

184 Ten pat, p. 124. O. Henri pateikia informaciją, paremtą britų šaltiniais, kad $1919 \mathrm{~m}$. rugsèjo 20 d. D. Britanijos užsienio reikalų ministerijos pareigūnas Wellesley informavo V. Čepinski, jog britai pripažino Lietuvą de facto (Hovi O. The Baltic Area in British Policy, p. 177). Tad pripažinimo dienos data skiriasi. Tai savo darbe pažymėjo ir istorikè E. Gruzdienė (Gruzdienė E. Užsienio valstybių karinès misijos pirmojoje Lietuvos Respublikoje 1919-1920 m., daktaro disertacija, p. 64-65).
}

${ }^{185}$ Senn A. E. Lietuvos valstybès atkūrimas 1918-1920, p. 123-124.

${ }^{186}$ Anderson E. Die Baltische Frage und die internationale Politik, S. 366-367. Kontekstas rodytų, jog kalba sukosi apie formalų teisinị pripažinimą. 
gen. H. Gougho veiksmais dèl Šiaurès vakarų Rusijos vyriausybès, britai pasistengè vengti kokių nors vienašalių užsienio politikos akcijų, kai kada iniciatyvą užleisdavo prancūzams, kartu slapčia vildamiesi, jog pastariesiems ne ką geriau seksis lyderiauti ${ }^{187}$.

O Lietuvos pripažinimas de facto tuo metu buvo labai vykęs žingsnis. Tai krašte sukèlè ne tik optimizmo, bet ir probritiškų nuotaikų bangą. Žinia apie pripažinimą Kaune èmé sklisti rugsèjo $26 \mathrm{~d} .{ }^{188}$ Tos pačios dienos popietę vos ne stichiškai mieste buvo organizuotas džiaugsmo išraiškos mitingas, ị kurị, pasak spaudos, suplūdo minios žmonių. Pasidžiaugę, pasiklausę oratorių kalbų prie rotušès ir prezidentūros, mitingo dalyviai nužygiavo prie plk. R. B. Wardo, o po to ir prie plk. H. Rowano-Robinsono misijų būstinių ${ }^{189}$. Pasitikti jų išèjo ne tik misijų vadovai, bet ir visas personalas, ir tai buvo pirmasis britų atstovų susitikimas su Lietuvos visuomene. Orkestras grojo abiejų valstybių himnus, minia džiūgavo ir kèlè ovacijas, o plk. R. B. Wardas ir plk. H. Rowanas-Robinsonas pasakè neilgas viešas kalbas. Retrospektyviai žvelgiant tai buvo neabejotinai ryškiausias D. Britanijos pasiuntinių veiklos Lietuvoje 1919 m. epizodas, be to, aiškiai pozityvus, nes britai galejo pasimėgauti populiarumu, atsidūrę dèmesio centre. Wardo ir Robinsono kalbas mitinguotojams taip pat galime vertinti ir kaip pirmą viešą, tiesioginị misijų tikslų ir uždavinių pristatymą Lietuvos visuomenei, šių dienų terminais kalbant - kaip tam tikrą viešųjų ryšių akciją. Tai ypač būdinga plk. R. B. Wardo kalbai, nes jis miniai papunkčiui išdèstė tolesnę savo misijos veiklos programą: 1) padèti išspręsti Lietuvos finansinius reikalus; 2) rūpintis prekybos ir pramonès kilimu; 3) stengtis tinkamai išspręsti Lietuvos sienų problemas ${ }^{190}$.

${ }^{187}$ Britų ir prancūzų konkurencinių santykių ypatumai labiau išryškèjo sudarant gen. H. A. Niesselio komisiją vokiečių pajègų iškraustymui iš Baltijos kraštų prižiūrèti 1919 m. spali (žr.: Hovi O. The Baltic Area in British Policy, p. 190-193).

${ }^{188}$ Rugsejjo 25 d. plk. R. B. Wardas informavo Lietuvos prezidentą apie tai, kad „Jo Didenybès Britanijos Karaliaus valdžia yra pranešusi Lietuvos atstovams savo sutikimą pripažinti laikinąją Lietuvos valdžią de facto <...> ir man yra įsakyta tatai pranešti Tamstai“. Turima pranešti informacija Wardo buvo gauta per Rygą iš Užsienio reikalų ministerijos (Anglai pripažįsta Lietuvos nepriklausomybę // Lietuva, 1919, Nr. 213, p. 1).

${ }^{189}$ Demonstracija Kaune rugsejjo 26 d. // Lietuva, 1919 , Nr. 214, p. 1-2.

${ }^{190}$ Kalba pulkininko Wardo // Lietuva, 1919, Nr. 216, p. 1. Oficiozas „Lietuva“ išspausdino tiek plk. R. B. Wardo, tiek plk. H. Rowano-Robinsono kalbas, pasakytas manifestuotojams. 
Pirmi du punktai atrodo nevienareikšmiški ir intriguojantys jau anksčiau minètame kontekste: kaip tik tą pačią rugsėjo 26 d. plk. R. B. Wardas lankèsi pas M. Sleževičių ir grasino nebeteikti kreditų, pagaliau rugsèjo 25 d. G. Curzono aplinkraštyje aiškiai užsimenama, kad D. Britanija nepajègi ekonomiškai ir finansiškai remti Baltijos valstybių. Savo kalboje plk. R. B. Wardas taip pat minejo „sunkius politinius laikus“ Lietuvos valdžiai, kol nesušauktas Steigiamasis Seimas, ir tai galbūt buvo užuomina apie M. Šleževičiaus vyriausybès krizę, prie kurios pats plk. R. B. Wardas prisidèjo ${ }^{191}$. Plk. H. Rowanas-Robinsonas savo kalboje pabrèžẻ kovos su gresiančiu bolševizmu, taip pat Lietuvos, Latvijos ir Estijos vienybės šioje kovoje reikšmę ${ }^{192}$. Pažymètina, jog, nors minia ir kèlė ovacijas, jos ir britų atstovų prioritetai nesutapo: žmonès skandavo ne antibolševikinius, o antilenkiškus ir prieš bermontininkus nukreiptus šūkius. Plk. H. RowanuiRobinsonui kalbant teko akivaizdžiai improvizuoti - miniai èmus šaukti: „Ginklų mums, ginklų!", kalbètojas pažadejjo pasistengti jų gauti iš savo valdžios, tačiau čia pat priminè, jog „jau keletą metų pasaulis plūsta kraujuose“, o reikia, „kad įvyktų taika ir ramybë“, ir prašè lietuvių pažadèti ginklų nenaudoti grobiamajam karui ${ }^{193}$. I tai jis išgirdo: „Vilnių! İsakykite,

${ }^{191}$ Č. Laurinavičius pateikia intriguojantį faktą: kai atsistatydino premjeras M. Sleževičius, tai išgirdęs Wardas net „pašokęs iš džiaugsmo“ (Laurinavičius Č. Lietuvos-Sovietų Rusijos taikos sutartis, p. 46). Tokia plk. R. B.Wardo pozicija, jo nepasitenkinimas dèl dešiniųjų pasitraukimo iš vyriausybès atrodo gana netikèta, turint omenyje minètus 1919 m. pavasarị užsimezgusius M. Sleževičiaus ir jo bendražygių (pirmiausia J. Šimkaus) gana artimus santykius su tiesioginiu Wardo viršininku S. Tallentsu. Galbūt tai būtų galima aiškinti kataliko R. B. Wardo didesne simpatija lietuvių dešiniųjų stovyklai. Tačiau, kaip aiškina Č. Laurinavičius, 1919 m. rudenị tai atspindejo ir D. Britanijos atstovų baimę dèl, jų nuomone, per didelio M. Sleževičiaus šalininkų radikalumo ir orientavimosi i „plačiuosius visuomenès sluoksnius“ (Laurinavičius Č. Lietuvos-Sovietų Rusijos taikos sutartis, p. 46-47). Vèliau, kaip minèta, plk. R. B. Wardas glaudžiai susigyveno su Lietuvos politiniais sluoksniais, tapo populiarus ir jokių aštrių iniciatyvų nekèlè.

192 Pulkininko Robinsono kalba // Lietuva, 1919, Nr. 216, p. 1. Robinsono kalba rodo, kad jis vadovaujasi pagrindiniais gen. H. Gougho misijos orientyrais, kurių esmè buvo kova su bolševizmu ir visų antibolševikinių jègų telkimas. Gen. H. Goughas dar Paryžiuje buvo sakęs T. Naruševičiui, jog rekomendavo Antantės Aukščiausiajai tarybai sudaryti Baltijos valstybių konfederaciją (Gaigalaitė A. Lietuva Paryžiuje 1919 metais, p. 59).

${ }^{193}$ Pulkininko Robinsono kalba // Lietuva, 1919, Nr. 216, p. 1. Jo pažadai dèl ginklų tuo metu turejo realų pagrindą: rugsèjo 23 d. Lietuvos kariuomenès vadas Silvestras Žukauskas pranešè krašto apsaugos ministrui, kad „anglai siūlo 10000 rusiškų šautuvų ir 
kad lenkai mums grąžintų Vilnių!“ Todèl taip pat buvo priverstas pažadèti prisidèti prie palankaus Lietuvai sienų nustatymo klausimo sprendimo ${ }^{194}$.

Apskritai britai 1919 m. rugsejjo pabaigoje-spalio pradžioje galejo būti patenkinti naujausiais savo politikos Baltijos šalyse rezultatais. Spalio $2 \mathrm{~d}$. Tartu vykusioje Baltijos šalių konferencijoje, S. Tallentso nuomone, D. Britanijos deklaruotas politinis Baltijos šalių pripažinimas de facto buvo labai veiksmingas keičiant anksčiau susidariusị ịspūdị, kad britụ vyriausybe், neteikdama pakankamai karinès ir finansinès paramos, tikèjosi, jog Baltijos valstybės tęs karą su bolševikais ${ }^{195}$. Tuo metu Lietuvoje džiaugsmo manifestacijos, susijusios su D. Britanijos paskelbtu pripažinimu, tęsèsi provincijoje: jos vyko Kelmèje, Šakiuose, Telšiuose, Virbalyje ir kitur ${ }^{196}$. Pripažinimas de facto neabejotinai žymèjo perèjimą i kitą Lietuvos ir D. Britanijos santykių etapą, kartu ir ị kitą karinio diplomatinio britų atstovavimo Lietuvoje fazę. Negreitai išsisklaidè šio įvykio sukelta euforija. Iš pirmo žvilgsnio abipusis palankumas ir simpatijos nekèlè abejonių, tačiau skirtingas akcentų dèliojimas manifestacijos Kaune metu, o svarbiausiai - tai, kad Lietuva vis dar nebuvo pripažinta de jure, rode, jog D. Britanijos pasiuntinių Kaune dar laukia nelengvas ir atsakingas darbas bendradarbiaujant su jauna demokratiniais pagrindais kuriama valstybe ir užmezgant su ja diplomatinejje praktikoje ịprastus dvišalius santykius.

Iteikta $2011 \mathrm{~m}$. spalio $11 \mathrm{~d}$.

10000000 šovinių, kuriuos reikia atsiimti iš Kraicburgo“ (Latvijoje). S. Žukauskas rekomendavo priimti pasiūlymą ir dèl jo skubiai pasitarti su plk. Robinsonu (1919 0923 kariuomenès vado S. Žukausko pranešimas krašto apsaugos ministrui. LCVA, f. 384, ap. 3, b. $354,1.64$ a. p.).

${ }^{194}$ Pulkininko Robinsono kalba // Lietuva, 1919, Nr. 216, p. 1.

${ }^{195}$ Gruzdienė E. Užsienio valstybių karinès misijos pirmojoje Lietuvos Respublikoje 1919-1920 m., daktaro disertacija, p. 65; Senn A. E. Lietuvos valstybès atkūrimas 1918-1920, p. 124.

${ }^{196}$ Tai rode lietuvių spaudos pranešimai, pvz.: Kelmietis, Spalio 5 d. Kelmèj ìvyko manifestacija // Lietuvos ūkininkas, 1919, Nr. 34, p. 6; Žinios iš Lietuvos // Lietuva, 1919, Nr. 246, p. 3; Šiandien čia suruošta demonstracija // Lietuvos ūkininkas, 1919, Nr. 33, p. 3; Žinios iš Lietuvos // Lietuva, 1919, Nr. 230, p. 2. 


\title{
REPRÉSENTATION DIPLOMATIQUE MILITAIRE DE GRANDE BRETAGNE EN LITUANIE JUSQU'À LA CONSÉCRATION ÉTATIQUE DE FACTO (décembre 1918 - septembre 1919)
}

\author{
Dr. Edmundas Gimžauskas, \\ Institut de l'histoire lituanienne
}

Quoique la Première guerre mondiale s'est fini en novembre 1918, les problèmes internationaux, particulièrement dans la région des pays baltes, est toujours actuelles. Une nouvelle situation géopolitique de cette région s'est formée. Jusquà ce moment-là, la région des pays baltes était le champ des relations entre l'Allemagne et la Russie, mais l'Allemagne a perdu la guerre, et l'empire de la Russie s'enfonçait dans le conflit civil et devenait le facteur sans aucune puissance à cause de bouleversement de Bolchevik. À la fin des années 1918, l'escadre de la flotte militaire britannique dirigée par le contramiral E. Sinclair, est parvenue les rivages de l'Estonie ainsi que de Lettonie, et s'y est postée pour la durée prolongée. Les premiers représentants militaires - diplomatiques arrivaient avec la flotte militaire et résidaient épisodiquement au Tallin et en Liepaja.

La relation à nouer entre le Lituanie et la Grande Bretagne retardait, d'une part c'était pour l'éloignement lituanienne des rivages de la mer Baltique, mais d'autre part - pour les barrières retrouvées à cause des allemandes. Seul le gouvernement de M. Sleževičius au début des années 1919 commençait à chercher vigoureusement des contacts avec la Grande Bretagne. Les contacts mutuels étaient établis par l'intermédiaire de Lettonie et par la communication avec ce pays, ainsi que par le but des lituaniens de se cramponner à Liepaja. Les premières conférences exhaustives entre les délégués lituaniens et les représentants britanniques survenaient donc spécialement à Liepaja au début de mars 1919. Suite à ces conférences, au début de mois d'avril le diplomate britannique H. Grant Watson séjournait en Lituanie, et cétait donc le premier visite de représentant britannique dans les terrestres de Lituanie.

En mai 1919, il était formé et envoyée dans la région une mission 
militaire dirigée par le général $\mathrm{H}$. Gough dont le but principal était une coordination de la lutte contre le régime de Bolchevik. La mission devait collaborer avec les représentants des armées et des gouvernements nationaux. En même temps le Ministère des affaires étrangères de Grande Bretagne a pris l'initiative de former une mission de type diplomatique et économique dirigé par le colonel S. Tallents et de l'envoyer dans le rivage oriental de la mer Baltique. Toutes les deux missions devaient donc établir ces groupes dans tous les trois pays baltes, mais l'application de ce fait s'est réalisée un peu plus tard à cause du facteur des allemandes.

Les représentants permanents de Grande Bretagne commençaient à s'instaurer en Lituanie à la fin d'aout 1919 : le groupe de la mission du colonel S. Talents dirigé par le colonel R. B. Ward, ainsi que le groupe la mission du générale $\mathrm{H}$. Gough dirigé par le colonel $\mathrm{H}$. Rowan-Robinson sont arrivés à Kaunas.

Des grands pays Occidentaux prenaient son temps avec la reconnaissance de la Lituanie et l'aide par rapport à ce pays, bien que les messagers donnent des promesses et l'espérance. La question concernant la Lituanie était tenue comme la partie des questions générales de la Russie et de la Pologne. La situation commençait à changer juste en aout 1919: tout d'abord les britanniques a décidé de soutenir les buts de l'indépendance des pays baltes. Cette décision était associée avec la détermination de Grande Bretagne à se retirer de l'intervention en Russie et à passer dans des relations plus pacifiques avec les soviétiques. Les britanniques décidaient donc à avouer de facto la Lituanie (l'Estonie et la Lettonie l'avaient déjà), en comparant la situation de tous les trois pays en espérant qu'ils vont conduire la politique de sécurité collective. C'était fait à la fin de septembre 1919. Toutefois les britanniques ne s'engageaient pas à aider les pays baltes. Malgré que la nouvelle de reconnaissance ait donné beaucoup de popularité pour la Grande Bretagne et pour ces représentants qui résidaient en Lituanie. Ces derniers avaient l'honneur à annoncer cette nouvelle pour la société et l'autorité lituaniennes, et ceetait le principal et le plus distinct accent de son présentation en Lituanie. 


\title{
MILITARY DIPLOMATIC REPRESENTATION OF GREAT BRITAIN IN LITHUANIA UNTIL DE FACTO RECOGNITION OF THE STATEHOOD (DECEMBER 1918 - SEPTEMBER 1919)
}

\author{
Dr. Edmundas Gimžauskas, \\ Lithuanian Institute of History
}

Although World War I ended in November of 1918, international problems, especially in the area of the Baltic Sea, were far from over during this period, perhaps they became even more complex. A new geopolitical situation of this region was being created. Until then, the Baltic area was actually the field of Russian-German relations; however, Germany lost the war, and the Russian Empire sank into civil conflict and because of the Bolshevik Revolution became a factor without the authority. At the end of 1918, British naval military squadron, led by Admiral E. Sinclair, reached the coasts of Latvia and Estonia and stayed there for a longer period of time. The first British military diplomatic representatives came with the Navy and occasionally resided in Tallinn and Liepaja.

Establishment of British relations with Lithuania were delayed due to the fact that Lithuania seemed too remote from the Baltic coast, and also because the Germans were interfering. Only at the beginning of 1919, M. Šleževičius' government started an active search for contacts with the British. The interrelationship was achieved through mediation of Latvians and cooperation with Latvia, as well as Lithuanians trying to establish themselves in Liepaja. The first comprehensive consultations between the Lithuanian delegates and the British representatives were held in Liepaja at the beginning of March 1919. The outcome of these meetings was the visit of a British diplomat $\mathrm{H}$. Grant Watson in Lithuania at the beginning of April; it was the first visit of a British representative in the Lithuanian lands.

In May of 1919, a military mission, led by Gen. H. Gough, was formed and sent to the region to coordinate the fight against Bolshevism. The mission was to collaborate with the representatives of national govern- 
ments and militaries. At the same time on the initiative of the Ministry of Foreign Affairs of Great Britain, diplomatic and economic mission, led by Colonel S. Tallents, has been formed and sent to the eastern Baltic coast. Both missions were to set up their branches in all three Baltic states; however, this was not fulfilled immediately in practice, primarily because of the German factor.

Only by the end of June in 1919, the situation has changed when joint Estonian and Latvian forces had beaten the forces of R. Von der Goltz at Cesis and thus suppressed the Germans.

Permanent British representatives began to settle in Lithuania at the end of August in 1919: the Colonel S. Tallents' Mission Division, led by Colonel R. B. Ward, and Gen. H. Gough's Mission Division, led by Colonel H. Rowan - Robinson, came to Kaunas.

Major Western countries did not rush to recognize the statehood of Lithuania and to support it, although messengers gave hopeful promises. The question of Lithuania was considered to be a part of the common Russian and Polish issue. Only in August of 1919, the situation started to change: firstly, again, the British decided to maintain aspirations of the Baltic States for independence. This was associated with the determination of Great Britain to withdraw from intervention in Russia and move on to more peaceful relations with the Soviets. The British decided to grant de facto recognition to Lithuania (Estonia and Latvia have already had one), and to equalize the situation of all three countries, hoping that they will conduct collective security policy. This was done at the end of September in 1919. Despite the fact that the British did not undertake to support the Baltic countries, the message of recognition provided Great Britain and the British representatives with much popularity in Lithuania. The latter had the honour to communicate this message to the Lithuanian authorities and to the public, and it had become a strong feature of their presentation in Lithuanian public. 